\title{
One More "Living Fossil": Mesozoic Lineage Differentiation, Morphological Stasis and Weak Phylogeographic Structure in Eurasia in the Bosminopsis Deitersi Group (Crustacea: Cladocera: Bosminidae)
}

Petr G. Garibian

A.N. Severtsov Institute of Ecology and Evolution

Dmitry P. Karabanov

Institut biologii vnutrennih vod imeni I D Papanina RAN

Anna N. Neretina

A.N. Severtsov Institute of Ecology and Evolution

Derek J. Taylor

University at Buffalo - The State University of New York

Alexey Kotov ( $\square$ alexey-a-kotov@yandex.ru )

A.N. Severtsov Institute of ecology and evolution https://orcid.org/0000-0002-8863-6438

\section{Research}

Keywords: Phylogeography, Phylogeny, Molecular clock, Taxonomy, Cladocera, Eurasia

Posted Date: July 24th, 2020

DOI: https://doi.org/10.21203/rs.3.rs-45963/v1

License: (a) (i) This work is licensed under a Creative Commons Attribution 4.0 International License.

Read Full License 


\section{Abstract}

Background: Water fleas (Crustacea: Cladocera) of the Family Bosminidae have been studied since the founding of paleolimnology and freshwater ecology. However, one species, Bosminopsis deitersi, stands out for its exceptional multicontinental range and broad ecological requirements.

Results: Here we use an integrated morphological and multilocus genetic approach to to address the species problem in $B$. deitersi. We analyzed 32 populations of $B$. deitersis. lat. Two nuclear and two mitochondrial loci were used to carry out the bGMYC, MPTP and STACEY algorithms for species delimitation. Detailed morphological study was also carried out across continents. The evidence indicated a widely distributed cryptic species in the Old World (Bosminopsis zernowi) that is genetically divergent from $B$. deitersi s.str. We revised the taxonomy and redescribed the species in this complex. Our sampling indicated that $B$. zernowi had weak genetic differentiation across its range. A molecular clock and biogeographic analysis with fossil calibrations suggested a Mesozoic origin for the Bosminopsis deitersi group.

Conclusions: Our evidence rejects the single species hypothesis for $B$. deitersiand is consistent with an ancient species group (potentially Mesozoic) that shows marked morphological conservation. The family Bosminidae, then, has examples of both rapid morphological evolution (Holocene Bosmina), and morphological stasis (Bosminopsis).

\section{Background}

Frey in 1962 [1] demonstrated morphological stasis for the water fleas (Cladocera) based on paleolimnological records from the Quaternary. He later based the paradigm of "non-cosmopolitanism" [2, 3] on this apparent longterm stability in morphology. According to non-cosmopolitanism, geographic differentiation occurred mainly due to vicariant events related to the disruption of Pangaea and the dispersal barriers imparted by subsequent continental drift. The process (often termed "continental endemism") now has strong support among "traditional" taxonomists [4-6] and molecular biologists [7, 8].

Frey's early insights on non-cosmopolitanism made the Cladocera[2, 9] a model group for freshwater animals. However, a transcontinental distribution for many freshwater taxa persists. One of these species reported from many continents is Bosminopsis deitersi Richard, 1895 (Cladocera: Bosminidae). After the first description of $B$. deitersi from La Plata [10], the species was found in many tropical regions[11-20] and temperate [21-30]. Citing minor morphological differences from $B$. deitersi (see checklist below), several related taxa were described from different regions. Burckhardt[31] concluded that there are three alternative views of the group's diversity: 1) at least eight local forms ("Lokalväriataten"), 2) multiple independent species, and 3) a single broadly distributed taxon, $B$. deitersi. Later he advocated 11 extant "taxa" in the group [32]. 
Burckhardt's view failed to gain support, with most authors recognizing that Bosminopsis is a monotypic genus [24, 25, 33-35]. Behning [36] and Manujlova [37] regarded some forms described by Burckhardt as regional subspecies, but gave very obscure diagnoses. At the end of the 20th century, the investigators of tropical populations from different continents [2,38-41] also assigned specimens to a single taxon, $B$. deitersi. Indeed, Koř́nek [42] directly stated that "Bosminopsis deitersi was regarded as the only species within the genus". However, in the last third of the 20th century, two species of Bosminopsis beyond the $B$. deitersi group were found in the Amazon River basin $[43,44]$.

B. deitersi, as presently described, has an unsually broad biogeographic range and ecological preference for a cladoceran species. Wolsky [45] wrote that Bosminopsis deitersi prefers "warm water". However, Pirozhnikov [27] detected Bosminopsis in high latitude waters of the Ob and Yenisei river deltas. Kotov [46] suggested that these North Eurasian populations belong to a separate taxon from $B$. deitersi, $B$. zernowi Linko, 1900.

An integrated approach, which combines molecular phylogeny, phylogeography, formal biogeography and morphological analysis has advanced the taxonomy of several difficult groups [47,48]. Here we use an integrated approach to address the taxonomy of the $B$. deitersi group. We find evidence that the group contains several related species with modest geographic ranges and weak morphological differentiation. We reconstruct this group's evolutionary history and provide evidence for the antiquity and morphological conservation of the genus Bosminopsis.

\section{Results}

\section{Phylogenetics and phylogeography}

We analyzed 118 specimens from 32 populations belonging to the $B$. deitersi group. The specimens originated mainly from Eurasia (Fig. 1), but a single population from North America and a single population from South America were also analyzed (Supplement Table 1).

Figure 1. Distribution of studies populations of Bosminopsis deitersi group belonged to two major phylogroups: B. zernowi (red rectangles) and Bosminopsis sp. (blue rectangle). Visualisation of the localities was made in DIVA-GIS7.5.0 (https://www.diva-gis.org) using free spatial GIS data from http://www.naturalearthdata.com as the layers.

We obtained 58 original sequences of $16 S, 15$ sequences of $C O I, 43$ sequences of $18 S$, and 75 sequences of 28S. Populations had a relatively high genetic polymorphism (Table 1). In contrast, the number of haplotypes was small. Each locus had a differing optimal substitution model (Supplement Table 2). 
Table 1

Metrics of genetic diversity from mitochondrial and nuclear loci in Bosminopsis.

\begin{tabular}{|c|c|c|c|c|c|c|c|c|c|c|}
\hline Loci & $\mathbf{N}$ & $\mathrm{n}$ & $S$ & h & $\mathrm{Hd}$ & $\mathrm{Pi}$ & $k$ & Fs & D & DemMod \\
\hline $\begin{array}{l}\text { COI } \\
\text { (mit.) }\end{array}$ & 16 & 415 & 100 & 2 & 0.125 & 0.038 & 12.5 & 17.06 & $-2.52^{\star}$ & PB (4.8) \\
\hline $\begin{array}{l}16 \mathrm{~S} \\
\text { (mit.) }\end{array}$ & 60 & 500 & 99 & 8 & 0.647 & 0.044 & 23.9 & 26.70 & -0.04 & PD (4.9) \\
\hline $\begin{array}{l}18 \mathrm{~S} \\
\text { (nucl.) }\end{array}$ & 43 & 562 & 6 & 5 & 0.221 & 0.001 & 0.36 & -3.02 & $-2.11^{*}$ & $n / d$ \\
\hline $\begin{array}{l}28 S \\
\text { (nucl.) }\end{array}$ & 75 & 377 & 50 & 5 & 0.392 & 0.039 & 14.3 & 26.25 & 0.99 & PB (0.01) \\
\hline \multicolumn{11}{|c|}{ 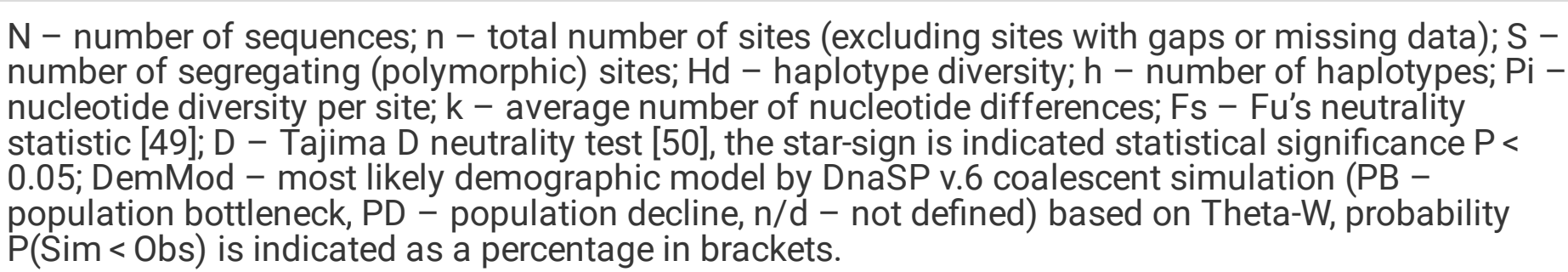 } \\
\hline
\end{tabular}

Three major clades of Bosminopsis deitersi group were revealed from a tree based on the mitochondrial dataset (Supplement Fig. 1A). The first clade was B. zernowi - widely distributed in Eurasia and represented by two sub-clades ( 1 and 2 ). The second clade was $B$. deitersi distributed in the Americas, it is represented by two sub-clades: 1 in South America (B. deitersi s.str.) and 2 in North America. Both geographic subclades had modest support. Further study is necessary to examine the independent status of North American populations. A third clade (Bosminopsis sp.) was detected from a single population in Thailand.

The tree based on the nuclear dataset $(18 S+28 S)$ had a similar topology to the mtDNA tree, but Bosminopsis sp. (from Thailand) absent from the tree based on nuclear genes. The large clade of $B$. zernowi was again subdivided into two subclades (1 and 2) with low support. There were some conflicts between mitochondrial and nuclear sequences. Some specimens from the mitochondrial sub-clade 1 belonged to the nuclear sub-clade 2 (they are marked by asterisks in Supplement Fig. 1A and 1B). As support for both mitochondrial and nuclear subclades was low, we do not discuss this below. The $18 \mathrm{~S}$ locus was almost identical in all populations, suggesting the locus is most informative at the genus level. The 285 locus demonstrated substantial variability in the D1 and D2 variable domains and appeared to contain information for taxa within the genus. Based on the neutrality tests and coalescent simulations in DnaSP v.6, we concluded that the most probable demographic model was a "bottleneck" model reflecting historical processes. 
The final tree based on combined mitochondrial and nuclear datasets (Supplement Fig. 1C) was fully congruent with the mitochondrial tree - major clades are well-supported. No conflicts were found between $\mathrm{ML}$ and $\mathrm{BI}$ (with unlinked data) trees for separate genes, mitochondrial and nuclear trees or the final consensus tree.

The results of all phylogenetic reconstructions suggested a deep demographic subdivision of the $B$. deitersi group. The tests of neutrality were consistent with such a division (Fu's Fs $<=0$ with Tajima D >> 0 ). The most probable demographic process in this group evolution was an expansion with a strong founder effect resulting in strong differentiation between populations. We further explored the genetic diversity within each group and addressed the taxonomic uncertainty within these lineages.

For cybertaxonomic taxon delimitations (Fig. 2), both bGMYC and mPTP (for both mitochondrial and nuclear genes) suggested a deep divergence within the $B$. deitersi group. All approaches suggested an independent status of B. zernowi, B. deitersi and Bosminopsis sp. from Thailand. Only the nuclear tree suggested a "Far Eastern" sub-clade based on the information in the hypervariable domains D1 and D2. There was some evidence that North American and South American populations of $B$. deitersi form independent species. More sampling of North American populations and loci is warranted to test this hypothesis further. Compared to bGMYC and mPTP, STACEY suggested significantly more taxa. However, increased splitting is expected (compared to morphological evidence) with STACEY [51, 52].

Figure 2. BI multi-locus tree based on the $\mathrm{COI}+16 S+18 S+28 S$ sequences, with a summary of results of the cybertaxonomic species delimitation by different methods. Analyses referring are based on mitochondrial (mit.), nuclear (nuc.) and multi-locus datasets (STACEY). Node supports are: UFboot2 (ML) and posterior probabilities $(\mathrm{BI})$, in percent for mitochondrial genes in the numerator and nuclear genes in the denominator.

To estimate divergences among selected OTUs, we calculated "simple" uncorrected $p$-distances for the best sampled locus, $16 S$ (Table 2). Bosmina was the outgroup. Distances among outgroups are ca. two times greater than the maximum distances within the B. deitersi groups. Groups "Eurasia", "Thailand", and "Americas" are well-differentiated, while differences between two sub-clades of Eurasia are less than $0.5 \%$. The two subclades may result from moderately separated mitochondrial lineages, which are common in cladocerans $[53,54]$. Again, North and South American populations may be separate species, but more sequences are needed to test this hypothesis. 
Table 2

Estimates of evolutionary divergence over sequence pairs between groups.

\begin{tabular}{|llllllll|}
\hline & Groups & $\mathbf{1}$ & $\mathbf{2}$ & $\mathbf{3}$ & $\mathbf{4}$ & $\mathbf{5}$ & $\mathbf{6}$ \\
\hline $\mathbf{1}$ & Eurasia & & 0.003 & 0.014 & 0.014 & 0.015 & 0.020 \\
$\mathbf{2}$ & Far East & 0.004 & & 0.014 & 0.014 & 0.015 & 0.020 \\
$\mathbf{3}$ & North America & 0.122 & 0.122 & & 0.014 & 0.017 & 0.021 \\
\hline $\mathbf{4}$ & South America & 0.116 & 0.112 & 0.128 & & 0.012 & 0.019 \\
\hline $\mathbf{5}$ & Thailand & 0.114 & 0.110 & 0.137 & 0.084 & & 0.020 \\
\hline $\mathbf{6}$ & OUT & 0.224 & 0.226 & 0.223 & 0.212 & 0.214 & \\
\hline
\end{tabular}

The number of base differences per site from averaging over all sequence pairs between groups are shown. Standard error estimates are shown above the diagonal and were obtained by a bootstrap procedure (100 replicates). This analysis involved 61 nucleotide $16 S$ sequences. All ambiguous positions were removed for each sequence pair (pairwise deletion option). There was a total of 507 positions in the final dataset. Evolutionary analyses were conducted in MEGA-X [55].

A network of $16 S$ mitochondrial haplotypes (Fig. 3) revealed that all populations from Northern Eurasia belonged to only four haplotypes (Fig. 2): haplotype $\mathrm{H} 1$ included $73 \%$ of studied specimens and distributed from the Volga basin in European Russia to Pacific coast including Sakhalin Island (but not in Korea and Japan). H2 haplotype was endemic to the Yenisey Basin in Eastern Siberia and seemed to be a derivate of $\mathrm{H} 1$. Another well-represented haplotype $(\mathrm{H} 3)$ differed by two substitutions from $\mathrm{H} 1$ and was associated with a rare haplotype $\mathrm{H} 4$. $\mathrm{H} 3$ and $\mathrm{H} 4$ were detected only in Japan and Korea. Overall, haplotypic differentiation within groups was weak.

Figure 3. A haplotype 16S network for Bosminopsis zernowi.

The Maximum Likelihood tests (Table 3) suggested that the hypothesis of molecular clocks is not rejected for each locus tested. In general, the topology of the tree constructed for the molecular clock calculations (Fig. 4A) is congruent with the multilocus tree described above. Differences in the divergence pattern of the American (B. deitersi) and Thailand (B. sp.) clades may be explained by heterochrony in the appearance and fixation of the substitutions in mitochondrial and nuclear genomes [56]. Minor heterochrony is not an insurmountable obstacle for phylogenetic reconstructions [57]. 
Table 3

Results of a molecular clock test using the Maximum Likelihood method.

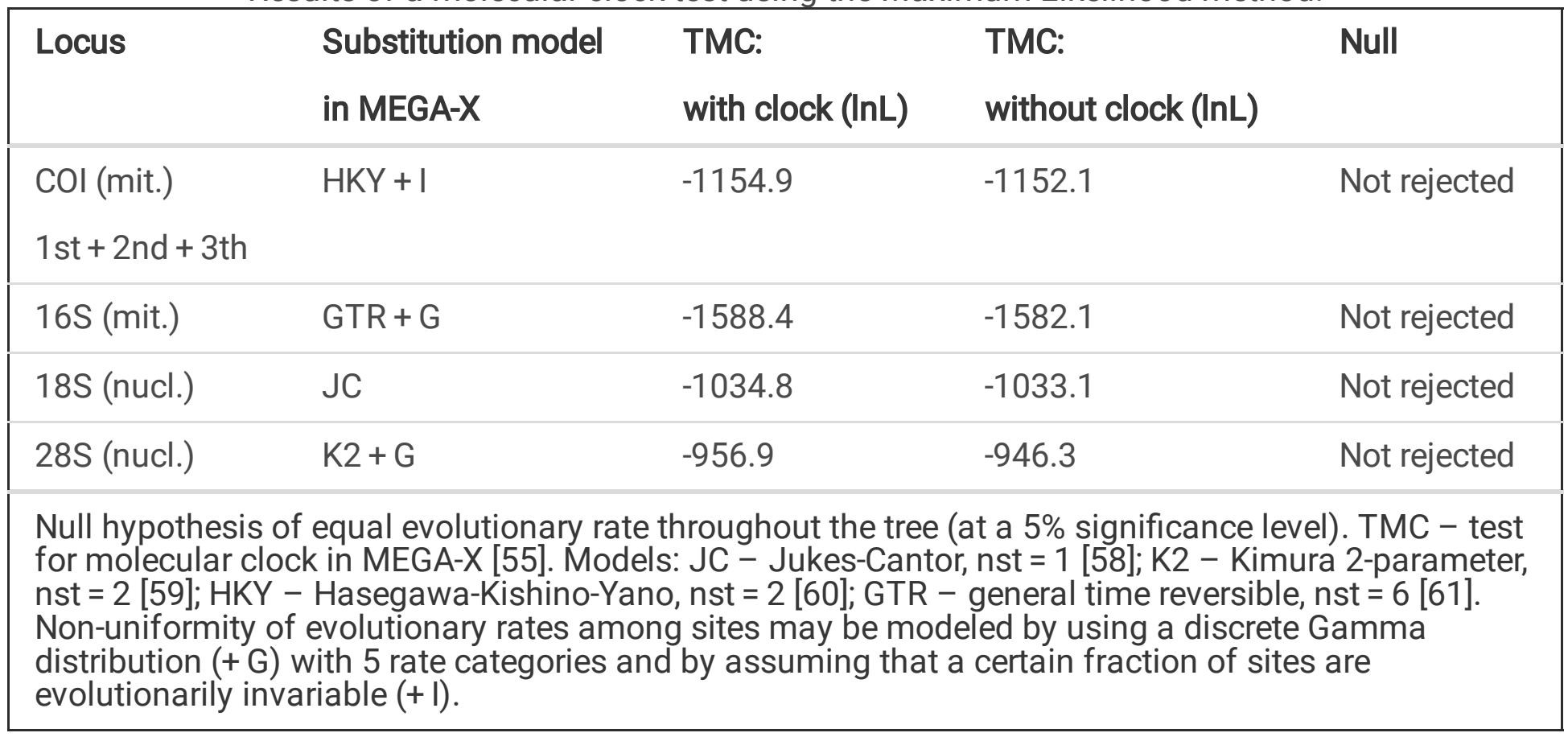

"Simple" $p$-distances between $B$. zernowi and $B$. deitersi (based on the COllocus), gave a divergence time estimate of 17-30 MYA ( $p=0.241)$. The estimate used an average divergence time for crustaceans of $c a$. 0.8-1.4\% per $1 \mathrm{Myr}$, which is similar to the age of divergence based on the coalescent model (Fig. 4A). Based on the time of divergence of the outgroup (Bosmina). We estimated the divergence of the $B$. deitersi group at around 200 MYA. Using RASP4, the taxa under consideration had an origin consistent with Laurasia (ancestral distribution range (C(ABCGEF)G), see Fig. 4B, 4C). However, note that Gondwanan populations from Africa, Australia, and India were not studied here. An alternative explanation is that the divergence of Bosminopsis sp. could be explained by its Gondwanan proto-range and subsequent colonization of Eurasia (i.e., due to India's continental drift). Bosminopsis sp. (ancestral range (G)) was separated in the Early Cretaceous from a Euro-Asian-American population of the group (CE(AB)GF)). Subsequent history was probably related to the disruption of Laurasia into Eurasian $(C A(B C G))$ and American (EF) groups of populations also in Cretaceous. Separation of North (F) and South American (E) populations had no ready explanation - it may be associated with the GondwanaLaurasia split in the Cretaceous or a significantly more recent dispersal event (Neogene). A strong founder effect could then explain the genetic differences between Neogene populations of the two continents. In any event, the divergence of the entire Bosminopsis group is likely very ancient (at least the Early Cretaceous) and potentially affected by the split of proto-continents.

Figure 4. Biogeographic history of B. deitersi group. A - A possible phylogenetic tree for four loci based on the strict molecular clock, speciation by Yule process. Alternative topology of mitochondrial tree is represented by dotted line. Stratigraphic chart according to the International Commission on Stratigraphy (2020). B - A proposed biogeographic history of the B. deitersi group on the consensus mitochondrial tree combined with the result of DIVALAKE $+\mathrm{J}$ model. Only tree topology is represented. Pie charts in each node demonstrate probabilities of alternative ancestral ranges; the most probable range is marked by the 
letter in the center. C - Possible ancestral ranges on palaeo-maps are represented at: 198 MYA, 72 MYA and 5 MYA. The maps are from the PalaeoAtlas for GPlates under General Public License (GPL) Ver. 2.

\section{Morphological analysis}

\section{Order Anomopoda Sars, 1865 \\ Family Bosminidae Baird, 1845}

Genus Bosminopsis Richard, 1895

Short diagnosis. Dorsal head pores absent in adults. Basal spine on postabdominal claw very large, as large as claw itself. Antennae I in females with proximal parts fused. Both exopod and endopod of antenna II three-segmented, antennal formula 0-0-3/1-1-3. Five pairs of thoracic limbs.

Checklist of the formal taxa in the genus Bosminopsis

1. 1. Bosminopsis deitersi Richard, 1895 - valid species.

2. 2. Bosminopsis zernowi Linko, 1901 - valid species.

3. 3. Bosminella Anisitsi Daday, 1903 - junior synonym of B. deitersi.

4. 4. Bosminopsis ishikawai Klocke, 1903 - junior synonym of B. zernowi.

5. 5. Bosminella Anisitsi var. africana Daday, 1908 - status must be checked, it could be a valid species.

6. 6. Bosminopsis deitersi var. typica Burckhardt, 1909 - junior synonym of $B$. deitersi.

7. 7. Bosminopsis deitersi birgei Burckhardt, 1924 - valid species.

8. 8. Bosminopsis deitersi brehmi Burckhardt, 1924 - junior synonym of B. africana.

9. 9. Bosminopsis deitersi klockei Burckhardt, 1909 - junior synonym of B. zernowi.

10. 10. Bosminopsis deirestsi pernodi Burckhardt, 1924 - possible junior synonym of B. zernowi.

11. 11. Bosminopsis deirestsi schroeteri Burckhardt, 1924 - junior synonym of B. zernowi.

12. 12. Bosminopsis stingelini Burckhardt, 1924 - junior synonym of $B$. deitersi.

13. 13. Bosminopsis deitersivar. africana Rahm, 1956 - junior homonym of $B$. africana.

14. 14. Bosminopsis negrensis Brandorff, 1976 - valid species, endemic of Brazil.

15. 15. Bosminopsis devendrari Rane, 1984 - species inquirenda, it could be a valid taxon from SE Asia.

16. 16. Bosminopsis macaguensis Rey \& Vasquez, 1986 - junior synonym of $B$. deitersi (see Kotov, 1997b).

17. 17. Bosminopsis brandorffi Rey \& Vasquez, 1989 - valid species, endemic of Brazil.

Unavalable name:

18. Bosminopsis granulata Daday - unpublished taxon name for Indian populations; slides of E. Daday labeled by this name are kept in the Collectio Dadayana of the Hungarian Natural History Museum, Budapest, Hungary. 
Diagnosis. Valve with a single mucro or several mucro-like spines at postero-ventral valve portion. No postero-dorsal spine (caudal needle) on carapace and inflated basis of postabdominal setae.

Comments. Among 17 available taxa listed above, 15 belong to the $B$. deitersi group. Only two valid species are not members of the $B$. deitersi group, both are andemics of Amazonia ( $B$. negrensis and $B$. brandorffi, numbers 14 and 17 in our checklist). Most taxa of the $B$. deitersi group were poorly described. Here we try to start the revision of the group, redescribing $B$. deitersi s.str. and B. zernowi. We do not have adequate material (i.e. populations with males and ephippial females) for revision of North American, SE Asian, African, and Australian taxa.

Bosminopsis deitersi Richard, 1895s.str.

Figures $5 A-E, 6-9$

Bosminopsis deitersi Richard 1895 [10], p. 96-98, Figs. 1-4; Richard 1897 [62], p. 283-286, Figs. 28-31; Stingelin 1904 [63], p. 584-586, PI. 20: Figs. 7-10; Burckhardt 1909 [31], p. 251; Burckhardt 1924 [32], p. 221-228; Rey and Vásquez 1986 [64], p. 222-225, PI. 2: Figs. 1-16; Kotov 1997a [65], p. 26-29, Figs. 1-2; Kotov 1997b [46], p. 6-26, Figs. 1-13; Kotov \& Ferrari 2010 [66], p. 51.

Bosminopsis deitersi var. typica n.n. in Burckhardt, 1909 [31], p. 251.

Bosminopsis stingelini Burckhardt 1909 [31], p. 251, text-figure: A-B; Burckhardt, 1924 [32], p. 228-229, Figs. 2, 8.

Bosminopsis macaguensis Rey and Vásquez 1986 [64], p. 220-222, Pl. 1: Figs. 1-18.

Bosminella Anisitsi Daday 1903 [11], p. 594-597, Figs. 1-3; Daday 1905 [67], p. 199-200, PI. 13: Figs. 1-5.

Type locality. "... l'eau douce à La Plata (Buenos-Ayres)" [10], Argentina.

Type material. Lost, absent in the Collection of Jules Richard at the National Museum of Natural History, U.S.A. [66].

Material studied here. See Supplement Table 1.

Short diagnosis. Body of large adult parhenogenetic female subovoid, in younger adults more elongated, with a short postero-dorsal spine, but a caudal needle absent. Reticulation well-expressed on valves and head. Valve with a single short mucro at postero-ventral valve portion, or it is completely reduced. Postabdomen without inflated basis of postabdominal setae. Limb I with epipopide having two finger-like projections. Juvenile female with a long postero-ventral mucro, supplied by minute denticles. Free and fused parts of antennae I, mucro, rostrum, ventral valve edge, base of caudal spine covered with small 
spinules. Ephippial female with egg chamber sculpture represented by large polygons. A strong medial keel on dorsum, strong paired lateral keels well distinguishable from the dorsal view. Adult male with dorsal contour of head humped, head large, with a smooth rostrum and expressed ocular dome, a short mucro always present postero-ventrally. Postabdominal claw bears a basal spine comparable in size with the latter. Antenna I free, remarkably curved distally. A relatively long (somewhat longer than exopod itself), curved at tip additional male seta on endopod apical segment in position of a rudimentary spine in female. Limb I a copulatory hook relatively large and regularly thick, its tip blunt. Size 0.17-0.41.

Figure 5. Bosminopsis deitersi Richard, 1895 from Rio Xingu (A), Lago do Castanho (B-D), Rio Tapajos (E) in Amazonia, Brazil, South America (A-E) and Bosminopsis sp. from Bung Pueng, Kalasin Province $(F)$ and Lake Bueng Khong Long, Nong Khai Province $(G-H)$ in Thailand $(F-H)$. A, Adult parthenogenetic female. B-D, Ephippial female, lateral, dorsal and anterior view. E, Juvenile female. F. Large adult parthenogenetic female. $G-H$, Juvenile female and its mucro. Scale bars: $A-G=0.1 \mathrm{~mm}, \mathrm{H}=0.01 \mathrm{~mm}$.

\section{Redescription}

Adult parthenogenetic female. Body short and almost round in lateral view (body height/length ratio about 0.65-0.69), dorsal margin regularly curved from base of antenna I to posterodorsal angle (Figs. 5A, $6 \mathrm{~A})$. Reticulation prominent, both on head and on valves. Posterior margin straight, with height about half of total body height, postero-dorsal angle expressed. Head in lateral view with a low ocular dome (Fig. 6B), body contour between head and proboscis rostral part (fused bases of antennae I) depressed. Frontal head pore ovoid, located almost in the middle of rostral part, somewhat anteriorly to level of frontal sensory setae (Fig. 6C-D). Lateral and dorsal head pores absent in adults. Compound eye of moderate size. Ocellus absent. Labrum as a fleshy appendage, its anterior contour convex. Antero-ventral portion of valves with setulated setae (Fig. 6E), ventral margin slightly convex, with a series of spinules, a long seta (seta Kurzi) and a rudimentary mucro at poster-ventral angle (Fig. 6F-G). Postabdomen compressed laterally, slightly and regularly narrowing distally, without infladed basis of postabdominal setae (Fig. 7A-C). Preanal margin long, straight to slightly concave, without setules. Anal margin straight, preanal angle expressed, but postanal angle absent. Anal and postanal portion with small denticles and as a postabdominal claw terminally supplied with a strong basal spine, almost as large as claw, both claw and basal spine slightly curved. Postabdominal seta bisegmented, shorter than postabdomen.

Figure 6. Bosminopsis deitersi Richard, 1895, parthenogenetic (A-I) and ephippial (J-K) females from Lago do Castanho and Lago Cristalino, both in Amazonas, Brazil. A, Adult parthenogenetic female, lateral view. B, Its head, lateral view. C-D, Head, anterior view. E, Postero-ventral portion of valve. F-G, Posteroventral portion of valve. H, Antenna I. I, Antenna II. J, Mature ephippial female, lateral view. K, Mature ephippial female, dorsal view. Scale bars $=0.1 \mathrm{~mm}$.

Proximal portions of two antennae I fused together and with rostrum, both lateral portions directed downwards and slightly curved laterally (Fig. 6C-D, H). Antennular sensory setae located on fused portion of antennas I. Distal portions with nine aesthetascs subequal in size. Antenna II (Fig. 6I) with a coxal portion bearing a long seta and a short seta on a conical elevation, elongated basal segment and 
short three-segmented exopod and endopod, antennal formula: setae 0-0-3/1-1-3; spines 0-0-1/0-0-1, but apical spines greatly reduced in size. All apical and lateral (on endopod first and second segment) setae subequal in size, covered by fine setules.

Limb I large, its corm conically narrowing distally. Epipodite (Fig. 7D: epp) with two long finger-like projections. Outer distal lobe (Fig. 7D: odl) with two setae of different size, feathered by sparse, long, robust setules. Inner subdistal lobe (in terms of Kotov 1997a) (Fig. 7D: isl) with a single seta, densely fringed by delicate setules. On inner limb edge, three soft setae. A bunch of long setules is located near these setae. Two robust ejector hooks (Fig. 7D: ejh) strongly different in size, armed with short denticles. The maxillar process (Fig. 7D: mxp), a derivative of gnathobase I, with a single long, densely setulated seta, at base of the limb.

Figure 7. Bosminopsis deitersi Richard, 1895, parthenogenetic female from Lago do Castanho, Amazonas, Brazil. A-C, Postabdomen, lateral view. D, Limb I. E, Limb II. F, Limb III. G, Gnathobase of limb III. H, Limb IV. I, Limb V. Scale bar $=0.1 \mathrm{~mm}$.

Limb II relatively small, with epipodite supplied by a finger-like projection. Inner limb portion with an anterior row of 6 setae (homologs of "scrapers" of the chydorids, see Fryer, 1968) (Fig. 7E: 1-6) and disjuncted posterior row two setae (Fig. 7E: pos): a seta near gnathobase and another one near the proximal end of the limb. Gnathobase II with distal armature (Fig. 7E: dag) of three setae of different armature. Filter plate consists of five long setulated setae (Fig. 7E: fpl).

Limb III with epipodite (Fig. 7F: epp) supplied with a finger-like projection. Exopodite rectangular, bearing two lateral (Fig. 7F: lat) and five (Fig. 7F: dis) distal setae. All these setae covered by long setules. Distal endite (in terms of Kotov 2013) with three anterior setae (Fig. 7F, G: 1-3): setae 1 and 2 long; seta 3 especially short. Proximal endite with two small anterior setae (Fig. 7F, G: 4-5). Eight soft setae on posterior face of limb, plus a seta of unclear homology (Fig. 7F: ?). Distal armature of gnathobase (Fig. 7F: dag) with three setae and a small sensillum. Filter plate (Fig. 7F: fpl) with five setae of subequal size.

Limb IV with small ovoid setulated pre-epipodite (Fig. 7H: pep) and a finger-like epipodite (Fig. 7H: epp). Exopodite circular with eight soft setae, no subdivision into lateral and distal setae. The longest seta covered by fine stiff setulae, others with long setules. The distalmost portion of exopodite as a densely setulated flat lobe. Inner distal portion with four anterior setae (Fig. 7H: 1-4); among them distal most setae 1 especially thick. Four thin long setae on posterior limb face. Distal armature of gnathobase (Fig. 7H: dag) with two elements represented by a thin sensillae. Filter plate (Fig. 7H: fpl) with four setae subequal in size.

Limb V (Fig. 7l) with a small, ovoid setulated preepipodite and an epipodite supplied with a long fingerlike projection. Exopodite with five soft setae covered by long setules. The distalmost portion of limv as a densely setulated flat lobe, two soft setae near it, two setulated setae of subequal length near gnathobase. Filter plate with two long setae. 
Juvenile female. Instar I has a dorsal head pore [46]. Body elongated, head relatively high, elevating over valves, without a cervical incision (Fig. 5E). Carapace with a short posterior spine and a long posterventral mucro, supplied with minute denticles. Antenna I relatively longer than in female. Free and fused parts of antennules, mucro, rostrum, ventral valve edge, base of caudal spine covered with relatively small spinules.

Ephippial female. Only dorsal portion of valves modified as compared to parthenogenetic female (Fig. 5B-D, 6J-K). Ephippium yellowish, ovoid, not clearly demarked from ventral and lateral portions of valves. Egg chamber with a single egg, elongated, its sculpture represented by large polygons well visible under light microscope with very clearly, minute wrinkles and tubercles in each polygon. A strong medial keel on dorsum, strong paired lateral keels well distinguishable from the dorsal view. From the dorsal view, keels projected laterally out of body contour.

Juvenile male. Body elongated, with a clear dorsal depression posteriorly to head (Fig. 8A-B). Head large, with ill-developed ocular dome (Fig. 8C-D). Armature of antero-ventral valve portion (Fig. 8E) as in female. Mucro well-developed (Fig. 8G-H). Postabdomen short, gonopores not wisible (Fig. 8I-J). Antennae I fused to rostrum, but their bases are not fused together (Fig. 9D). Limb I with a short, thick copulatory hook (Fig. 8K-M).

Figure 8. Bosminopsis deitersi Richard, 1895, juvenile male from Lago do Castanho (Amazonas, Brazil). $A-B$, Lateral view. C, Head, lateral view. D, Head, anterior view. E-F, Antero-ventral portion of valve. G-H, Postero-ventral portion of valve. I-J, Postabdomen. K-M, Limb I. Scale bars $=0.1 \mathrm{~mm}$.

Adult male. Shape significantly different from that in female, body short (body height/length ratio about 0.65), dorsal contour of head humped, dorsal contour of carapace straight, valve anterior portion with few setae anteriorly, ventral margin convex, with setules as in female (Fig. 9A). Head large, with a smooth rostrum and expressed ocular dome, compound eye large (Fig. 9B-C). Valve armature as in female (Fig. 9D), but a short mucro always present postero-ventrally (Fig. 9E). Postabdomen similar with that in female, its ventral margin slightly comvex, preanal margin slightly to moderately concave. Anal margin almost straight, postanal angle absent. Postabdominal claw bears a basal spine comparable in size with the latter (Fig. 9F), both claw and basal spine slightly and regularly bent.

Figure 9. Bosminopsis deitersi Richard, 1895, adult male from Lago do Castanho, Amazonas, Brazil. A-B, Lateral view. C, head, anterior view. D, Antero-ventral portion of valve. E, Postero-ventral portion of valve. F, Postabdomen. G, Antenna I. H, Antenna II. I, Limb I. Scale bars $=0.1 \mathrm{~mm}$.

Antenna I free, remarkably curved distally (Fig. 9G). Frontal sensory seta long, located at middle of antennular body, a short male seta somewhat anteriorly to that, several fields of short spinules located at antenna I anterior face. Long aesthetascs located subterminally, two of them are located on the tip of antenna I, the others located on its lateral surface in two rows. Antenna II with apical and lateral setae as in female. A relatively long (somewhat longer than exopod itself), curved at tip additional male seta on endopod apical segment in position of a rudimentary spine in female (Fig. 9H). Limb I with outer distal 
lobe bearing two setae strongly unequal in size, copulatory hook relatively large and regularly thick, its tip blunt, not expanded bearing small denticles (Fig. 9l).

Size. $0.17-0.41 \mathrm{~mm}$.

Differential diagnosis. $B$. deitersi differs from $B$. zernowi in (1) only a single mucro at postero-ventral valve angle in both females and males; (2) male basal spine on postabdominal claw significantly shorter that the claw itself; (3) male antenna I strongly bent distally; and (4) additional seta on apical segment of male antenna II curved at tip. Morphological differences from other taxa revealed above genetically are not studied yet.

Distribution and ecology. Widely distributed in the Neotropical zone. Records from Mexico [68] and Central America [16] need to be checked as they could belong to $B$. deitersi s.str. or the poorly described $B$. birgei.

Populations with a single mucro in juveniles are present on other continents (Fig. 5F-H), but they belong to other taxa that need to be revised.

Bosminopsis zernowi Linko, 1901

Figures $10-14$

gen.? sp.? in Zernov 1901 [69], p. 34, Pl. 4: Fig. 27.

Bosminopsis zernowi Linko 1901 [21], p. 345-347, text-fig.; Meissner 1902 [70], p. 52; Meissner 1903 [71], p. 180-190, Plates 2-4; Zykoff 1906 [72], p. 22-24, text-fig.; Burckhardt 1909 [31], p. 251; Burckhardt 1924 [32], p. 229-230.

Bosminopsis deitersi zernowi in Behning 1941 [36], p. 190-191, Fig. 83; Manujlova 1964 [37], p. 265, Fig. $147(1,3)$.

Bosminopsis deitersi in Krasnodębski 1937 [33], p. 357-360, Pl. 12: Fig. 1; Smirnov et al. 1995 [40], p. 66, Fig. 58 (1-2); Song \& Mizuno 1982 [73], p. 343, Fig. 2-3; Yoon \& Kim 1987 [74], p. 194, Fig. 8e-g; Kim 1988 [75], p. 58, Fig. 40; Lieder 1996 [76], p. 29-31, Fig. 1a-c, 2a-f; Tanaka 2000 [28], p. 110, Fig. 1-2; Yoon 2010 [35], p. 94-95, Fig. 49; Jeong et al. 2014 [29], p. 221; Bledzki \& Rybak 2016 [77], p. 172.

Bosminopsis ishikawai Klocke 1903 [78], p. 130-134, Figs. 5-8, Pl. 4: Figs. 2, 6; Burckhardt 1924 [32], p. 222.

Bosminopsis klockei Burckhardt 1909 [31], p. 251; Burckhardt 1924 [32], p. 222.

Bosminopsis pernodi Burckhardt 1909 [31], p. 251; Burckhardt, 1924 [32], p. 222.

Bosminopsis deitersi pernodi in Manujlova 1964 [37], p. 265. 
Bosminopsis schroeteri Burckhardt 1909 [31], p. 251; Burckhardt 1924 [32], p. 229, Fig. 1, 4, 6-7.

Type locality. "Flusse Wjatka gefunden" = the Vyatka River (affluent of the Kama River which is a large affluent of Volga) near Malmyzh [69], Kirov Area, European Russia.

Type material. Lost.

Material studied here. See Supplement Table 1.

Figure 10. Bosminopsis zernowi Linko, 1900 from Sai-no-Kami Ike, Japan (A, C, G), Lake llinskoe, Primorsky Territory, Russia (B, D, F, H) and Lena River near Yakutsk, Yakutia Republic, Russia (E). A, Adult parthenogenetic female. $B-D$, Ephippial female in lateral and dorsal view and sculpture of ephippium. $E$, Pre-ephippial female. F-G, Juvenile female; $H$, Juvenile male II. Scale bars: $A-C, E-H=0.1 \mathrm{~mm}, D=$ $0.01 \mathrm{~mm}$.

Short diagnosis. Body of large adult parhenogenetic female (Figs. 10A, 11A-B) subovoid, in younger adults more elongated, with a short postero-dorsal spine, but a caudal needle absent. Reticulation illexpressed on valves and head (Fig. 11C-D). Valve (Fig. 11E-H) with a series of mucro-like spines at postero-ventral valve portion, or they are completely reduced. Postabdomen without inflated basis of postabdominal setae (Fig. 12A-C). Antenna I and II (Fig. 11I-J) as in previous species. Limb I with epipopide having two finger-like projections, limbs as in previous species (Fig. 12D-M). Juvenile female (Fig. 10F-G) with a series of long, thin mucro-like spines. Free and fused parts of antennae I, mucro, rostrum, ventral valve edge, base of caudal spine covered with small spinules. Ephippial female (Figs. 10B-D, 11K-L) with egg chamber sculpture represented by large polygons, but this sculpture is less represented as compare too previous species. A strong medial keel on dorsum, strong paired lateral keels well distinguishable from the dorsal view. Juvenile male (Fig. 10H, Fig. 13) as in previous species. Adult male with a dorsal contour of head humped (Fig. 14A); head large (Fig. 14B-C), with a smooth rostrum and expressed ocular dome, a series of mucro-like spines always present postero-ventrally. Valve as in female (Fig. 14D-E). Basal spine on postabdominal claw shorter than the claw itself (Fig. 14F). Antenna I free, its distal portion only slightly bent (Fig. 14C, G). A long additional male seta on endopod not curved at tip (Fig. 14H). Limb I with a copulatory hook (Fig. 14I) relatively more massive that in previous species.

Size. $0.25-0.47 \mathrm{~mm}$.

Figure 11. Bosminopsis zernowi Linko, 1901, large parthenogenetic females from Ivankovskoe Water Reservoir on Volga River, Tver' Area, European Russia (A-J) and mature ephippial female from a tributary of Dnepr River near Kremenchug, Poltava Area, Ukraine (K-L). A-B, Lateral view. C, Head, lateral view. D, Head, anterior view. E, Setae at antero-ventral valve portion. F-H, Spines at postero-ventral valve margin. I, Antenna I. J, Antenna II. K, Ephippial female, lateral view. L, Its dorsal view. Scale bars $=0.1 \mathrm{~mm}$.

Figure 12. Bosminopsis zernowi Linko, 1901, parthenogenetic female Ivankovskoe Water Reservoir on Volga River, Tver' Area, European Russia. A-C, Postabdomen. D, Limb I. E, Ejector hooks I. F, Limb II. G, 
Distal armature of its gnathobase. H, Limb III. I, Its inner-distal portion. J, Granthobase III. K, Limb IV. L, Its inner-distal portion. M, Limb V. Scale bar $=0.1 \mathrm{~mm}$.

Figure 13. Bosminopsis zernowi Linko, 1901, juvenile male of instar II $(A, C-G, I, K)$ and instar I (B, H, J) from Lake Livadijskoe, Primorski Territory, Far East of Russia. A-B, Lateral view. C, Head, lateral view. D, Its anterior view. E, Antero-ventral valve portion. F-G, Posterior portion of valve. H-I, Postabdomen. J-K, Limb I. Scale bars $=0.1 \mathrm{~mm}$.

Figure 14. Bosminopsis zernowi Linko, 1901, adult male from Lake Livadijskoe, Primorski Territory, Far East of Russia. A, Lateral view. B, Head, lateral view. C, Its anterior view. D, Valve antero-ventral portion. E, Posterior portion of valve. F, Postabdomen. G, Antenna I. H. Antenna II. I, Limb I. Scale bars = $0.1 \mathrm{~mm}$.

Differential diagnosis. It differs from $B$. deitersi in (1) several mucro-like spines at postero-ventral valve angle in both females and males; (2) male basal spine on postabdominal claw approximately as long as claw itself; (3) male antenna I almost not bent distally; (4) additional seta on apical segment of male antenna II without curved tip.

Distribution. In Europe, B. zernowi is recorded from the Neman basin in Poland [45], Dniepr River basin (including Dnepr itself, Desna and Pripyat, in Ukraine and Belarus, and, most probably, the Russian portion of the basin) [79-82]. Bledzki and Rybak [77] included the Danube basin as the part of its range, but no records from this river are known to us. Negrea [83] wrote that the species "could be present in Romania", but to date it was not recorded from this country. In European Russia, B. zernowi was recorded from many rivers of the Volga basin, including the Volga itself, Kostroma, Wyatka, Kama, Kerzhenets, Sura, Kubra, Oka, Nara, and Moskva rivers [70, 72, 84-91]. The species was found in the basins of all the Great rivers of Western and Eastern Siberia: the Ob' River basin [92] including its Arctic portion [93], the Tom' River [94] and the Chulym River [95]; Subarctic portion of the Yenisey River [27]; Lena River [96], Amur River basin [97]. The opinion of Manujlova [37] that "in the USSR it was not found east to Ob' River" was based on inadequate knowledge of previous literature, i.e. [27]. It is widely distributed in Korea [98] (also see descriptions above) and Japan [24] (and our data), and present in South China and Vietnam (our data). Most probably, it is present on the Pacific coast of Asia from the Amur to the Mekong basins.

But previous records from China [23, 34, 99-102] need to be checked, as they could belong both to $B$. zernowi (Amur basin) (i.e. $[25,26]$ ) and the SE Asia taxon (at least some populations in southernmost China). "B. schröteri" described from "Sutschaufluss bei Schanghai" [31], is a junior synonym of $B$. zernowi (as it has several mucro-like spines at postero-ventral angle).

Most probably, the tropical countries of Asia are fully populated by other taxa, as in all illustrations the females have a single strong mucro $[39,103,104]$. Also, a single mucro is illustrated in the figures of Bosminopsis from North America [22], Africa [42] and Australia [38] (Fig. 15).

Figure 15. Schematic representation of distribution of two major morphotypes of the juvenile parthenogenetic female: with several mucro-like spines (red) and a single mucro (blue). Visualisation was 
made in free software DIVA-GIS7.5.0 (https://www.diva-gis.org) using free spatial GIS data from http://www.naturalearthdata.com as the layers. Symbols are inserted manually.

\section{Discussion}

\section{Old Mesozoic group}

Our results are consistent with the hypothesis that $B$. deiters $i$ is, in fact, a species group. We find no evidence for the nominate species in the Palearctic. However, we did find evidence for a genetically divergent and morphologically differentiated Old World lineage. Notably, the strong genetic divergences that we observed and our ancient age estimates were unaccompanied by strong morphological divergences. With our integrated approach, we hoped to mitigate some of the limitations of molecular datasets. As coalescent analyses can oversplit taxa, multigene data benefit from morphological and ecological information. Single gene datasets may disagree with one another and with the species tree for manifold reasons $[105,106]$. In the present analysis, the topological disagreements (e.g. subclades) were weakly supported, indicating that random error may play a role.

A mature biogeography is only possible with an understanding of timescale [107]. The antiquity of cladocerans of different ranks, from genera to orders, has been confirmed by the fossil record, i.e., from the Mesozoic [108-112]. Unfortunately, the Palaeozoic records [113, 114] are dubious: the described animals could belong to the Cladocera, but also could be members of other crustacean groups [4]. Kotov and Taylor [111] demonstrated that extant genera of the Daphniidae and even the subgenera of the genus Daphnia existed at the Jurassic/Cretaceous boundary, ca. 145 MYA. More fossil calibrations are possible for the group.

Efforts to use fossil calibrations with molecular data have been limited for Cladocera [115-117]. Perhaps the only known calibration point for relaxed molecular clocks is the Daphnia/Ctenodaphnia/Simocephalus split at 145 MYA [111]. Non-calibrated molecular clocks also suggest earlier differentiation of the cladocerans, i.e., differentiation of the subfamilies within Chydoridae in the mid-Palaeozoic [115]. A fast molecular clock estimate gave a divergence time for Daphnia at more than 66 MYA [117]. This value is probably too young given the calibration point of 145 MYA. A more realistic estimate should exceed the minimum fossil calibration [118].

The Family Bosminidae contains only the genus Bosmina and the genus Bosminopsis. Our very rough estimation (see Fig. 4A) suggests that the Bosminidae could be even older than the Daphniidae. Such a conclusion agrees with the hypothesis that bosminids are a sister group to Chydoridae [118]. Chydorids are probably of Palaeozoic origin [115]. No Mesozoic bosminids are known to date. Bosmina was one of the first genera to be studied with paleolimnology. Unlike Bosmina, subfossil remains for Bosminopsis are unknown from the Holocene and Pleistocene bottom sediments [119, 120]. It seems unlikely that a detailed fossil record will be found for Bosminopsis. So molecular clocks are the only method to estimate the time of its differentiation. We estimate that the differentiation of the main Bosminopsis lineages took 
place in the Cretaceous, and coincided with the disruption of Pangaea, or later disruption of Laurasia. Mesozoic lineages survived in SE Asia and elsewhere in Eurasia (the exact location is unclear) after a mass extinction during the mid-Caenozoic [4, 121]. Most probably, the Pacific Coast Region ("Far East") was the center of $B$. zernowi diversificaton, as this region is the richest in mitochondrial haplotypes (Fig. 3), and is often a center of diversity for cladoceran taxa [54].

While there is strong genetic divergence between New World and Old World lineages, a more detailed assessment of the divergence time awaits further geographic and genomic sampling for the New World. Within $B$. zernowi, our results suggest a mitochondrial differentiation in the mid-late Caenozoic (or even Quaternary), but the divergence of its mitochondrial haplotypes was weak.

Korovchinsky [121] postulated that extant cladocerans are relicts of a mass extinction in the mid-late Caenozoic. For Cladocera, Pleistocene mass extinction in the Holarctic due to glaciation and aridization [122] also has phylogeographic support $[123,124]$. But phylogeographic publications referring to previous epochs with non-Holarctic samples are rare [7, 54]. For Bosminopsis, our results suggest a Mesozoic differentiation of the lineages and then survival of only two main lineages in the mid-Caenozoic. We failed to detect divergences consistent with the Quaternary. Our results are consistent with contintental endemism and longterm morphological stasis.

Morphological divergence in Bosmniposis appears to be weak since the Mesozoic. This divergence involves fine-scaled characters such as the mucro-like spine number, male basal spine, and antenna I appearance and armature. Such subtle differences among species are known in other cladoceran groups [54] but can only rarely be associated with a timescale.

There are no known fossil records for the globally distributed $B$. deitersi group. However, Bosminopsis may be a "living fossil" sensu Darwin [125]. The $B$. deitersi group has survived with very little morphological change since the Mesozoic despite profound abiotic and biotic changes to the continental water bodies over this timescale. Our results indicate that the occupation of differing climates has also left a weak morphological signature. While the concept of "living fossil" is somewhat ambiguous[126] there are several groups that appear to have undergone morphological stasis since the Mesozoic. Our evidence is consistent with Frey (1962) who expected stasis to account for continental endemism in Cladocerans.

\section{Preliminary comments on further taxonomic revision}

Further studies are needed to demonstrate that the North American populations form a separate species from South American specimens. If so, then the taxonomic name for North American specimens would be Bosminopsis birgei Burckhardt, 1924. Records of Bosminopsis are infrequent in North America and are mainly from the southeastern USA [30, 127]. Recent biotic exchange between North America and South America has occurred for several cladoceran genera [128]. In such cases, there is very little genetic differentiation for mitochondrial markers among continents. The status of populations from East Asia [39] must also be addressed, including that of $B$. devendrari Rane (a possible proper name for the SE 
taxon recorded above). To date, we have no information on Bosminopsis cf. deitersi from Africa, i.e., described by Daday [129] from Lake Nyassa as Bosminella Anisitsi var. africana with a single mucro. This taxon is found in different African countries [12, 14, 42]. The status of Australian populations [38], also having single mucro, remains unclear.

Subtle geographic variation in the morphology of Bosminopsis has been known since the early 1900's. Meissner[71] and Klocke [78], for example, pointed out the numerous stout spines at the postero-ventral corner of the valves from Russian and Japanese Bosminopsis - the most prominent difference between $B$. deitersi and $B$. zernowi. Still, subsequent authors failed to recognize this variation as taxonomically valuable. Klocke[78] concluded that there are two species in Japan, $B$. ishikawai and $B$. deitersi. He concluded that the former has stronger denticles on antenna I, better-developed reticulation, a posterodorsal projection located more dorsally and longer spines at postero-dorsal angle "making it similar to Ilyocryptus". In reality, all listed differences are characteristic of juvenile females. Therefore, Klocke[78] erroneously regarded the populations with large adults and without large adults those as two separate species. The same mistake was made by Rey and Vasquez [64], who described B. macaguensis referring to differences of juvenile males of $B$. deitersi in Venezuelan populations [65].

\section{Conclusions}

Here we revised only populations from Eurasia. Other taxa discussed above in the genetic section must be reconsidered in the future, and biological differences must be studied in detail. Each of these putative species has a single mucro at a postero-dorsal angle and minimal differences between parthenogenetic females. We expect that comparing males will be the most fruitful for assessing morphological diagnoses, as male morphology tends to differ among species more than female morphology in cladocerans $[130,131]$.

\section{Material And Methods}

\section{Collecting samples and morpholohical analysis}

Samples from different localities were collected via small-sized plankton nets (with mesh size $50 \mu \mathrm{m}$ ) and fixed via $4 \%$ formaldehyde or $96 \%$ ethanol in the fields, using conventional techniques. All samples were initially examined using a stereoscopic microscope LOMO. Individuals of Bosminopsis were initially identified via available references using morphological features $[46,65,132]$. Existing museum samples were used for morphological analysis (see the list of material in Supplement Table 1).

The morphology of populations from the Neotropics and the Palaearctic was examined in detail to assess the presence of taxonomically significant characters. Specimens of Bosminopsis from presorted samples were selected under a binocular stereoscopic microscope LOMO. They were then studied in toto under optical microscopes (Olympus BX41 or Olympus CX 41) in a drop of glycerol formaldehyde or a glycerol-ethanol mixture. Then, at least two parthenogenetic females, two ephippial females, and two 
males (if available) from each locality were dissected under a stereoscopic microscope for appendages and postabdomens. Drawings were prepared using a camera lucida attached to the optical microscopes.

Some individuals from Neotropical and Palaearctic localities were dehydrated in an ethanol series $(30,50$, $70,95 \%)$ and $100 \%$ acetone and then dried from hexametyldisilazane. Dried specimens were mounted on aluminum stubs, coated by gold in S150A Sputter Coater (Edwards, United Kingdom), and examined under a scanning electron microscope (Vega 3 Tescan Scanning Electron Microscope, TESCAN, Czech Republic).

\section{DNA extraction, amplification and sequencing}

Each specimen was accurately identified by morphological characters (Supplement Table 1). Genomic DNA was extracted from single adult females using the Wizard Genomic DNA Purification Kit (Promega Corp., Madison, WI) and QuickExtract DNA Extraction Solution (Epicentre by part Illumina, Inc., Madison, WI) using manufacturer's protocols. Two mitochondrial and two nuclear markers were investigated here: (1) the 5 '-fragment of the first subunit of mitochondrial cytochrome oxidase (COI) - a protein-coding marker widely used in DNA barcoding [133]; (2) the 5'-fragment of the mitochondrial 12S rRNA gene (12S) with a structure demonstrating an alternation of highly conservative duplexes and variable loops [134]; and (3-4) 5'-fragments of the nuclear ribosomal genes ( $18 S$ and $28 S$ ). Each fragment contains both long conservative portions and two variable domains. Although these nuclear markers are predominantly used for divergent taxa [135], they are informative at the species level for many microcrustaceans [136].

Primers used for amplification are listed in Table 4. Polymerase chain reactions (PCR) were carried out in a total volume of $20 \mu \mathrm{l}$, consisting of $2 \mu \mathrm{l}$ of genomic DNA solution, $1 \mu \mathrm{l}$ of each primer $(10 \mathrm{mM}), 6 \mu \mathrm{l}$ of double-distilled $\mathrm{H}_{2} \mathrm{O}$ and $10 \mu \mathrm{l}$ of ready-to-use PCR Master Mix 2X solution (Promega Corp., Madison, WI). PCR products were visualized in a $1.5 \%$ agarose gel stained with ethidium bromide and purified by QIAquick Spin Columns (Qiagen Inc., Valencia, CA). The PCR program included a pre-heating of 3 min at $94^{\circ} \mathrm{C}$; 40 cycles (initial denaturation of $30 \mathrm{sec}$ at $94^{\circ} \mathrm{C}$, annealing of $40 \mathrm{sec}$ at a specific temperature, an extension of $80 \mathrm{sec}$ at $72^{\circ} \mathrm{C}$ ); and a final extension of $5 \mathrm{~min}$ at $72^{\circ} \mathrm{C}$ (Table 4). Each PCR product was sequenced bi-directionally on the ABI 3730 DNA Analyzer (Applied Biosystems) using the ABI PRISM BigDye Terminator v.3.1 kit at the Syntol Co, Moscow. The authenticity of the sequences was verified by BLAST comparisons with published cladoceran sequences in mBLAST [137].

The sequences from this study were submitted to the NCBI GenBank database for $16 \mathrm{~S}$ acc. no. MT757174-MT757231, for COI acc. no. MT757459-MT757473, for 18S acc. no. MT757232-MT757274 and for $28 S$ acc. no. MT757314-MT757388. 
Table 4

Genes, primers and annealing temperatures used in this study of the Bosminopsis deitersi species complex.

\begin{tabular}{|c|c|c|c|c|c|}
\hline Gene & Primers & Sequence 5'-3' & $\begin{array}{l}\text { Temp. } \\
\left({ }^{\circ} \mathrm{C}\right)\end{array}$ & $\begin{array}{l}\text { Amplicon } \\
\text { length }\end{array}$ & Reference \\
\hline \multirow[t]{2}{*}{$\mathrm{COI}$} & COI_Bosm_F & TGTAACAGCTCACGCATTTG & $50-54$ & 415 & This paper \\
\hline & COI_Bosm_R & АCCTGCTAGAACGGGAAGAC & $50-54$ & & This paper \\
\hline \multirow[t]{2}{*}{$16 S$} & 16S-ar5 & CGCCTGTTTATC AA AACAT & $46-57$ & $500-506$ & [138] \\
\hline & 16S-br3 & CCGGTCTGAACTCAGATCACGT & $46-57$ & & [138] \\
\hline \multirow[t]{2}{*}{$18 \mathrm{~S}$} & $18 \mathrm{a} 1$ & CCTAYCTGGTTGATCCTGCCAGT & $52-59$ & 562 & [139] \\
\hline & $700 \mathrm{R}$ & CGCGGCTGCTGGCACCAGAC & $52-59$ & & [139] \\
\hline \multirow[t]{2}{*}{$28 S$} & D1a & CCCSCGTAAYTTAAGCATAT & $48-50$ & $370-373$ & [139] \\
\hline & D2b2 & CGTACTATTGAACTCTCTCTT & $48-50$ & & [139] \\
\hline
\end{tabular}

\section{Population analysis, alignment and phylogenetic analysis}

Nucleotide diversity analysis [140] and neutrality tests were carried out using DnaSP v.6.12 [141]. We applied the Fs [49] and D [50] tests to confirm neutrality and describe demographic processes in Bosminopsis population [142, 143]. To determine the most probable demographic model for Bosminopsis sequences, we performed a coalescent simulation for each locus (1000 replications) in DnaSP v.6.12 [141] using five demographic models (Standard Neutral Model, Population Growth, Population Decline, Population Bottleneck, Population Split/Admixture). The best model was selected based on the Theta-W (theta with Watterson) estimator [140, 144].

Alignment of sequences from each locus was carried out using the MAFFT v.7 algorithm [145] available on the server of the Computational Biology Research Center, Japan (http://mafft.cbrc.jp). For the proteincoding gene COI, we used the "Translation Align" option with the FFT-NS-i strategy. For alignment of the ribosomal-coding loci, we used the Q-INS-i strategy (secondary structure is considered by this algorithm). Linking sequences and their partitioning for subsequent analyses were made in SequenceMatrix v.1.8 [146].

The best-fitting models of the nucleotide substitutions for each locus and for linked data were selected using ModelFinder v.1.6 [147] at the Center for Integrative Bioinformatics Vienna web-portal, Austria (http://www.iqtree.org) [148] based on minimal values of the Bayesian information criteria (BIC) [149]. The BIC model parameters were almost identical to those obtained using the corrected Akaike's information criterion, AICc.

For the COllocus, the substitution model was partitioned by the nucleotide position of codons (1st, 2nd, 3th). In our opinion, independent phylogenetic analysis for each locus is more correct as compared to 
uniting of different loci based on general models of the nucleotide substitutions. Mechanical lumping leads in some average probabilities on substitutions bases on theoretical models instead of empirical facts. We believe that quality of phylogenetic reconstruction is higher in case of using of the information from all the trees, We used the multi-taxon coalescence model "star" in BEAST2 [150] and an partitioned models method using numerous models [151]. Phylogenetic reconstructions based on the maximum likelihood (ML) and Bayesian (BI) methods were made for each gene separately, the full set of mitochondrial genes, the full set of nuclear genes, and for all "unlinked" genetic data. We did not exclude sequences with incomplete and missed data as such exclusion can strongly reduce the accurateness of phylogenetic reconstruction [152].

We used the IQ-TREE v.1.6.9 algorithm [153] via a web-portal CIBIV, Austria for ML tree estimation. Each set of sequences was analysed based on the best model found automatically by the W-IQ-TREE [148]. To estimate the branch support values, we used UFboot2 [154]. The Topology of the ML trees was evaluated based on PhyML SH-like tests [155], performed in the block Building Phylogenetic Tree in uGENE v.34 [156]. BI analysis was performed in BEAST2 v.2.6.2 [157], with all of the parameters of the substitution model using the BIC criterion from BEAUti v.2.5.2 [158]. In each analysis, we conducted four independent runs of MCMC (40M generations and a sampling interval of $10 \mathrm{k}$ generations), with effectiveness control in Tracer v.1.7 [159]. A consensus tree based on the maximum clade credibility (MCC) was obtained in TreeAnnotator v.2.5.2 [158] with a burn-in of at least $20 \%$. Because the main clades for $\mathrm{BI}$ and ML were congruent, we presented the BI trees, with ML branch support/ BI posterior probabilities for key nodes.

A haplotype network was constructed for Bosminopsis zernowi (the most sampled taxon in this study) in popART v.1.7 with the Integer Neighbor-Joining Network algorithm [160] and minimal reticulation tolerance.

\section{Cybertaxonomic species delimitation based on DNA data}

Our approach to cybertaxonomic taxon delimitation was described in a previous paper [54]. An integrated approach based on genetic species delimitation combined with "traditional" morphological taxonomy was used to estimate the species richness. We used the bGMYC, MPTP and STACEY algorithms for species delimitation [161].

The general mixed Yule-coalescent model (GMYC) was made to assign analyzed individuals to the species according to ultrametric time trees derived from single-locus data [162]. But the "classical" GMYC has limitations [163]. We used the Bayesian GMYC model in the 'bGMYC' package[164] for the statistical language "Microsoft R-Open and MKL" 64-bit v.3.5.3 (http://mran.microsoft.com/). Ultrametric trees for each mitochondrial and nuclear datasets were evaluated in BEAST2. For MCMC, we used 50M generations with a sampling interval of $50 \mathrm{k}$ trees. We used Tracer v.1.7 to evaluate the convergence of parameters (based on ESS > 200). Sequences of Triops and Bosmina were used as outgroups. Sorting, rerooting of the trees and outgroup deletion was carried out in " $R$ " according to the script of [165]. For the bGMYC analysis, we randomly selected 100 ultrametric trees from the 1000 trees after burn-in from BEAST2. The results were accepted as statistically significant at a modified $\mathrm{P}>0.99$ level. 
Analysis of Multi-rate Poisson Tree Processes (mPTP) [166], which is most useful for datasets with small genetic distances [167] albeit prone to "splitting" [52], was performed on the web-server of Heidelberg Institute for Theoretical Studies (http://mptp.h-its.org/). As the input trees, we used the phylogenetic BI trees from BEAST2 and the ML-tree obtained using W-IQ-TREE for each locus. Delimitation results were congruent for separate loci and were composed of mitochondrial and nuclear datasets.

The combined species tree estimation and species delimitation analysis for STACEY (Species Tree And Classification Estimation, Yarely) [51], was made in BEAST2. Genealogical relationships were estimated by STACEY with four independent generations (50M generations of MCMC, sampling of every $10 \mathrm{k}$ generation) after incorporating the suggestions from an initial run. STACEY log files were examined with Tracer v.1.7 to evaluate the convergence of parameters based on ESS $>400$. Supports for the tree topologies estimated by STACEY were examined by constructing a maximum clade credibility tree using TreeAnnotator v2.6 (part of the BEAST2) after discarding half of all estimated trees. Species delimitations based on the trees estimated by STACEY were assessed using the Jones' java-application speciesDA (http://www.indriid.com/software.html).

\section{Phylogenetic reconstruction and molecular clock}

Two approaches were used for molecular clock estimation. A strict molecular clock [168] was based on the assumption of a relatively regular mutation rate in mitochondrial genes. The speed of mutation accumulation differs among organisms. For the crustaceans the rate is ca. $0.11-2.4 \%$ per MYA $[53,116$, $169,170]$. Apparently this is a very rough estimation [171]. An alternative is a stochastic approach based on the "calibration" of the molecular clocks by paleontological data and subsequent strict proof mathematical analyses.

To estimate the probability of molecular clock-like data, we applied a Maximum Likelihood method implemented in MEGA-X v.10.1.8 [55]. A Maximum Likelihood substitution model was estimated for each locus (separately for each nucleotide position for translated genes, and jointly for non-translated fragments). We used the best model as selected by the lowest BIC (Bayesian Information Criterion) scores and an ML tree with Bosmina as the outgroup.

For determination of the relative rate of substitutions, we used both paleontological information [111] and points based on molecular phylogenetic data [116]. As calibration points (with 15\% standard deviations), we used the following estimates: Triops/ all groups 340 MYA, Daphnia/ Simocephalus 145 MYA, Cyclestheria groups 120 - 70 MYA, and Bosmina / Bosminopsis without an exact date. The age of lineage differentiation according to a strict molecular clock model was estimated in BEAST v.1.10.4 [172] with a Yule speciation model as the most proper for datasets with several potential species [173]. Four independent runs of $50 \mathrm{M}$ generations were done, with each $100 \mathrm{k}$ tree sampled. Subsequent analysis was performed as above for BI following the recommendations [174].

\section{Phylogeographic reconstructions}


To test phylogeographic models, we used the packet BioGeoBEARS [175] with the integrated statistical package of the "R" language in RASP4 v.4.2 [176]. The data set was composed based on the maximum number of geographic localities and representation of all phylogenetic lineages revealed by cybertaxonomic methods. We reconstructed a phylogenetic tree based on sequences of two mitochondrial genes ( $\mathrm{COl}$ and $16 \mathrm{~S}$ ) for all main locations in the distribution range of Bosminopsis cf. deitersi. A mitochondrial phylogeny has some advantages, such as the absence of recombination. Objective software limitations allowed us to analyze only 27 sequences from five phylogenetic lineages and seven main geographic regions.

We tested six biogeographic models in BioGeoBEARS (standard dispersion-vicariant, and those with a correction for speciation events $+J$ ), estimated according to the AlCc_wt criterion [177]. A phylogeny for RASP4 was reconstructed in BEAST2. In each analysis, we conducted four independent runs of MCMC (40M generations, with a sampling interval of $10 \mathrm{k}$ generation). The best model according to the maximum AICC_wt value was DIVALIKE $+\mathrm{J}$, which takes into consideration new lineage origin upon colonization by a founder without the existence of a widely distributed ancestor [178]. For estimates of the age of historical processes, we used an outgroup "calibration". Palaeoreconstruction was performed in GPlates v.2.2 [179] with PALEOMAP PaleoAtlas v.3 by Christopher R. Scotese (https://www.earthbyte.org/paleomap-paleoatlas-for-gplates/).

\section{Abbreviations}

Abbreviations for collections

MGU ML

collection of Zoological Museum of Moscow State University.

Abbreviations in illustrations and text

I

V-thoracic limbs I-V; dag-distal armature of gnathobase; dis-distal setae of exopodite; ejh-ejector hooks on limb l; epp-epipodite; ext-exopodite; fpl-filter plate of gnathobase; lat-lateral setae of exopodite; mxp-maxillar process of limb l; odl-outer distal lobe of limb l; pep-preepipodite; posposterior setae; sdl-inner subdistal lobe of limb I.

\section{Declarations}

\section{Acknowledgements}

Many thanks to E.S. Certoprud, D.E. Gavrilko, L. Hovind, S. Ishida, H.G. Jeong, N.M. Korovchinsky, W.H. Piel, D.E. Shcherbakov, A.Y. Sinev for zooplankton samples, K.S. Chae, H.J. Dumont, B.P. Han, S.J. Ji, H.S. Kim for assistance during sampling. SEM works are carried out at the Joint Usage Center "Instrumental Methods in Ecology" at A.N. Severtsov Institute of Ecology and Evolution of Russian Academy of Sciences. Sampling in South Korea is supported by a grant from of the National Institute of Biological Resources (NIBR), funded by the Ministry of Environment (MOE) of the Republic of Korea. 


\section{Authors' contributions}

PG and AN conducted all morphological analysis, DK, DT and AK made all genetic works and subsequent analysis of phylogenetic information, all authors participated in the writing of different portions of the manuscript.

\section{Funding}

This study was supported by the Russian Science Foundation (grant no. 18-14-00325 for PGG. DPK, ANN and AAK). DJT has no specific support.

\section{Availability of data and materials}

All data generated or analysed during this study are included in Open Science Framework project (https://osf.io/4fjnm/) and this published article. All sequences are deposited at the NCBI GenBank accs. no. MT757174-MT757274, MT757314-MT757388, MT757459-MT757473. Specimen series from wich DNA was extracted are deposited at Zoological Museum of Moscow State University.

\section{Ethics approval and consent to participate}

Field collection in Russia was carried out by our team and our colleagues as part of several governmental projects with permission to collect samples from public property. Verbal permissions to collect in private ponds were obtained from local owners. Samples from South Korea were collected under cooperation with the National Institute of Biological Resources (AAK) and special permission from the Ministry of Environment of the Republic of South Korea. The sample from Arkansas, USA was obtained from collections resulting from a previous NSF grant. The samples from Japan, China, and Thailand were provided by our colleagues having permissions to collect them due to their scientific activity in the governmental institutes in the corresponding countries. Formol samples from Brazil were kept in the Collection of Zoological Miseum of Moscow State University for a long time, they were collected before the time when Brazil introduced very strct regulations for sampling. The species were not assessed as endangered at the time of collection and are currently not subject to specific regulations, however all efforts were taken to ensure that the collection and preservation of animals was performed with due consideration of their welfare. The number of individuals taken did not represent a significant proportion of the population present at each site.

\section{Consent for publication}

Not applicable.

\section{Competing interests}

The authors declare that they have no competing interests.

\section{Author details}


${ }^{1}$ Laboratory of Aquatic Ecology and Invasions, A.N. Severtsov Institute of Ecology and Evolution of Russian Academy of Sciences, Moscow 119071, Russia. ${ }^{2}$ Laboratory of Fish Ecology, I.D. Papanin Institute for Biology of Inland Waters of Russian Academy of Sciences, Borok 152742, Yaroslavl Area, Russia. ${ }^{3}$ Department of Biological Sciences, the State University of New York at Buffalo, Buffalo, USA.

\section{References}

1. Frey DG. Cladocera from the Eemian interglacial of Denmark. J Paleontol. 1962;36:1133-54.

2. Frey DG. Questions concerning cosmopolitanism in Cladocera. Arch Hydrobiol. 1982;93:484-502.

3. Frey DG. The taxonomy and biogeography of the Cladocera. Hydrobiologia. 1987;145:5-17. doi:10.1007/BF02530260.

4. van Damme K, Kotov AA. The fossil record of the Cladocera (Crustacea: Branchiopoda): Evidence and hypotheses. Earth Sci Rev. 2016;163:162-89. doi:10.1016/j.earscirev.2016.10.009.

5. Smirnov NN, Kotov AA. On morphological radiation of Cladocera (Crustacea). Invert Zool. 2018;15:231-48. doi:10.15298/invertzool.15.3.03.

6. Neretina AN, Kotov AA, van Damme K. A new case of false "wide" distribution for tropical cladocerans: the genus Notoalona Rajapaksa \& Fernando, 1987 (Crustacea: Cladocera) in the Old World. Zootaxa. 2019;4615:489-510. doi:10.11646/zootaxa.4615.3.5.

7. Xu S, Hebert PDN, Kotov AA, Cristescu ME. The noncosmopolitanism paradigm of freshwater zooplankton: Insights from the global phylogeography of the predatory cladoceran Polyphemus pediculus (Linnaeus, 1761) (Crustacea, Onychopoda). Mol Ecol. 2009;18:5161-79. doi:10.1111/j.1365-294X.2009.04422.x.

8. Heads MJ. Molecular panbiogeography of the tropics. Berkeley: University of California Press; 2012.

9. Frey DG. The non-cosmopolitanism of chydorid Cladocera: implications for biogeography and evolution. Rotterdam: A.A.Balkema; 1987.

10. Richard J. Description d'un nouveau Cladocere, Bosminopsis deitersi, n. gen., n.sp. Bull Soc Zool Fr. 1895;20:96-8.

11. Daday E von. Eine neue Cladoceren-Gattung aus der Familie der Bosminiden. Zool Anz. 1903;26:594-7.

12. Brehm V. Cladoceren. Wissenschaftliche ergebnisse der zweiten deutschen Zentral Africa-Expedition 1910-1911 unter Fuhrung Adolf Friedrichs. Leipzig: Klinkhardt \& Biermann; 1913.

13. Brehm V. La fauna microscópica del lago Peten, Guatemala. An. Esc. nac. Cienc. biol. Mex. 1939;1:173-203.

14. Rahm U. Cladoceren aus den Regenwaldgebiet der Elfenbeinkuste. Verh Naturforsch Ges Basel. 1956;67:239-68.

15. Dumont HJ. Cladocera and free-living Copepoda from the Fouta Djalon and adjacent mountain areas in West Africa. Hydrobiologia. 1981;85:97-115. doi:10.1007/BF00006620. 
16. Collado C, Fernando $\mathrm{CH}$, Sephton D. The freshwater zooplankton of Central America and the Caribbean. In: Dumont HJ, Tundisi JG, editors. Tropical Zooplankton. Dordrecht: Springer Netherlands; 1984. pp. 105-19. doi:10.1007/978-94-017-3612-1_8.

17. Dumont HJ. The Nile River system. In: Davies BR, Walker KF, editors. The Ecology of River Systems. Dordrecht: Springer Netherlands; 1986. pp. 61-88. doi:10.1007/978-94-017-3290-1_3.

18. Tanaka S, Ohtaka A. Freshwater Cladocera (Crustacea, Branchiopoda) in Lake Tonle Sap and its adjacent waters in Cambodia. Limnology. 2010;11:171-8. doi:10.1007/s10201-009-0291-7.

19. Korovchinsky NM. Cladocera (Crustacea: Branchiopoda) of South East Asia: history of exploration, taxon richness and notes on zoogeography. J Limnol. 2013;72:109-24. doi:10.4081/jlimnol.2013.s2.e7.

20. Kotov AA, van Damme K, Bekker El, Siboualipha S, Silva-Briano M, Ortiz AA, et al. Cladocera (Crustacea: Branchiopoda) of Vientiane province and municipality, Laos. J Limnol. 2013;72:81-108. doi:10.4081/jlimnol.2013.s2.e6.

21. Linko A. Bosminopsis (J. Richard) im europaischen Russland. Zool Anz. 1901;24:345-7.

22. Birge EA. The water fleas (Cladocera). In: Ward HB, Whipple GC, editors. Freshwater biology. New York: John Wiley \& Sons; 1918. pp. 676-740.

23. Ueno M. Contributions to the knowledge of the Cladocera fauna of China. Int Rev Gesamten Hydrobiol Hydrogr. 1932;27:234-51. doi:10.1002/iroh.19320270112.

24. Ueno M. Order Branchiopoda (Class Crustacea). Fauna Nipponica. 1937;9:1-135.

25. Ueno M. Cladocera of Manchoukuo. Int Rev Gesamten Hydrobiol Hydrogr. 1937;35:199-216. doi:10.1002/iroh.19370350113.

26. Ueno M. Cladocera of Manchoukuo. Phyllopoda of Manchoukuo. In: Reports of Limnology Survey in Kwantung and Manchoukuo, Dairen. Kwantung: Kwantung Ministry of Civil; 1940. 323-67, 368-381.

27. Pirozhnikov PL. Zooplankton of the Yenisey River and Yenisey Bay and its role in the fish feeding. Trudy Vsesoyuznogo Arkticheskogo Instituta. 1937;98:1-61.

28. Tanaka S. A taxomonic revision of Japanese Bosminidae (Crustacea, Cladocera). Research Report of the Scientific and Cultural Center of Toyama City. 2000;23:109-25.

29. Jeong H, Kotov AA, Lee W. Checklist of the freshwater Cladocera (Crustacea: Branchiopoda) of South Korea. Proc Biol Soc Wash. 2014;127:216-28. doi:10.2988/0006-324X-127.1.216.

30. Beaver JR, Renicker TR, Tausz CE, Vitanye BT. Distribution of six taxa in the family Bosminidae Baird (Crustacea: Branchiopoda: Anomopoda) in the plankton of lakes and reservoirs within the continental United States, including expanded range of the invasive cladoceran Bosmina (Eubosmina) coregoni Baird. Zootaxa. 2018;4407:506-20. doi:10.11646/zootaxa.4407.4.3.

31. Burckhardt G. Neues uber das Bosminopsis Richard = Bosminella Daday. Zool Anz. 1909;34:248-53.

32. Burckhardt G. Wissenschaftliche Ergebnisse einer Reise um die Erde von M. Pernod und C. Schroter. III. Zooplankton aus ost- und sud-asiatischen Binnengewassern. Zeitschrift fur Hydrologie. 1924;2:217-42. 
33. Krasnodebski F. Wioslarki (Cladocera) Zahorynia (Polesie). Archiwum Hydrobiologii i Rybactwa. 1937;10:344-412.

34. Chiang S-c, Du NS. Crustacea: freshwater Cladocera. Peking: Science Press; 1979.

35. Yoon SM. Arthropoda. Branchiopoda: Anostraca, Notostraca, Spinicaudata, Laevicaudata, Ctenopoda, Anomopoda, Haplopoda Branchiopods. Invertebrate fauna of Korea. 2010;21:1-156.

36. Behning AL. Kladotsera Kavkaza - The Cladocerans of the Caucasus. Tbilisi: Gruzmedgiz Publishing; 1941.

37. Manujlova EF. The cladocerans of fauna of the USSR. Moscow: Nauka.

38. Smirnov NN, Timms BV. A revision of the Australian Cladocera (Crustacea). Rec Aust Mus Suppl. 1983;1:1-132. doi:10.3853/j.0812-7387.1.1983.103.

39. Michael RG, Sharma BK. Fauna of India and adjacent countries. In: Indian Cladocera (Crustacea: Branchiopoda: Cladocera). Calcutta: Zoological Survey of India; 1988.

40. Smirnov NN. Check-list of the Australian Cladocera (Crustacea). Arthropoda Sel. 1995;4:3-6.

41. Sanoamuang L-O. Contributions to the knowledge of the Cladocera of north-east Thailand. Hydrobiologia. 1997;362:45-53. doi:10.1023/A:1003111401684.

42. Korinek V. Cladocera. In: Symoens J-J, editor. Hydrobiological Survey of Lake Bangweulu and Luapulu River Basin. Bruxelles: Cercle Hydrobiologique de Bruxelles; 1984. pp. 1-117.

43. Brandorff G-O. A new species of Bosminopsis (Crustacea, Cladocera) from the Rio Negro. Acta Amaz. 1976;6:109-14. doi:10.1590/1809-43921976061109.

44. Rey J, Vasquez E. Bosminopsis brandorffi n.sp. (Crustacea, Cladocera) une nouvelle espece de Bosminidae des systemes Amazone et Orenoque. Ann Limnol - Int J Lim. 1989;25:215-8. doi:10.1051/limn/1989022.

45. Wolski TB. Bosminopsis deitersi Richard, eine fur Polen neue Cladoceren-Art. Fragm Faun Mus Zool Pol. 1932;1:439-47. doi:10.3161/15053970FF1932.1.16.439.

46. Kotov AA. Studies on the morphology and variability of Amazonian Bosminopsis deitersi Richard, 1895 (Anomopoda Bosminidae). Arthropoda Sel. 1997;6:3-30.

47. Dayrat B. Towards integrative taxonomy. Biol J Linn Soc. 2005;85:407-15. doi:10.1111/j.10958312.2005.00503.x.

48. 10.1111/j.1095-8312.2010.01528.x

Padial JM, La Riva I de. A response to recent proposals for integrative taxonomy. Biol J Linn Soc. 2010;101:747-56. doi:10.1111/j.1095-8312.2010.01528.x.

49. Fu YX. Statistical tests of neutrality of mutations against population growth, hitchhiking and background selection. Genetics. 1997;147:915-25.

50. Tajima F. Statistical method for testing the neutral mutation hypothesis by DNA polymorphism. Genetics. 1989;123:585-95.

51. Jones G. Algorithmic improvements to species delimitation and phylogeny estimation under the multispecies coalescent. J Math Biol. 2017;74:447-67. doi:10.1007/s00285-016-1034-0. 
52. Vitecek S, Kucinic M, Previsic A, Zivic I, Stojanovic K, Keresztes L, et al. Integrative taxonomy by molecular species delimitation: Multi-locus data corroborate a new species of Balkan Drusinae micro-endemics. BMC Evol Biol. 2017;17:129. doi:10.1186/s12862-017-0972-5.

53. Bekker El, Karabanov DP, Galimov YR, Haag CR, Neretina TV, Kotov AA. Phylogeography of Daphnia magna Straus (Crustacea: Cladocera) in Northern Eurasia: Evidence for a deep longitudinal split between mitochondrial lineages. PLoS One. 2018;13:e0194045. doi:10.1371/journal.pone.0194045.

54. Kotov AA, Garibian PG, Bekker El, Taylor DJ, Karabanov DP. A new species group from the Daphnia curvirostris species complex (Cladocera: Anomopoda) from the eastern Palaearctic: taxonomy, phylogeny and phylogeography. Zool J Linn Soc. 2020:zlaa046. doi:10.1093/zoolinnean/zlaa046.

55. Kumar S, Stecher G, Li M, Knyaz C, Tamura K. MEGA X: Molecular Evolutionary Genetics Analysis across Computing Platforms. Mol Biol Evol. 2018;35:1547-9. doi:10.1093/molbev/msy096.

56. Vawter L, Brown WM. Nuclear and mitochondrial DNA comparisons reveal extreme rate variation in the molecular clock. Science. 1986;234:194-6. doi:10.1126/science.3018931.

57. Allio R, Donega S, Galtier N, Nabholz B. Large variation in the ratio of mitochondrial to nuclear mutation rate across animals: implications for genetic diversity and the use of mitochondrial DNA as a molecular marker. Mol Biol Evol. 2017;34:2762-72. doi:10.1093/molbev/msx197.

58. Jukes TH, Cantor CR. Evolution of protein molecules. In: Munro HN, editor. Mammalian protein metabolism. New York: Academic Press; 1969. pp. 21-132. doi:10.1016/B978-1-4832-3211-9.500097.

59. Kimura M. A simple method for estimating evolutionary rates of base substitutions through comparative studies of nucleotide sequences. J Mol Evol. 1980;16:111-20.

60. Hasegawa M, Kishino H, Yano T-a. Dating of the human-ape splitting by a molecular clock of mitochondrial DNA. J Mol Evol. 1985;22:160-74. doi:10.1007/BF02101694.

61. Rodriguez F, Oliver JL, Marin A, Medina JR. The general stochastic model of nucleotide substitution. J Theor Biol. 1990;142:485-501. doi:10.1016/s0022-5193(05)80104-3.

62. Richard J. Entomostraces de l'Amerique du Sud, recueillis par MM. U. Deiters H, von Ihering, G. W. Muller et C. O. Poppe. Mem Soc Zool Fr. 1897;10:263-301.

63. Stingelin T. Entomostracen, gesammelt von Dr. G. Hagmann in Mundungsgebiet des Amazonas. Zool Jahrb Abt Syst Geogr Biol Tiere. 1904;20:575-90.

64. Rey J, Vasquez E. Bosminopsis macaguensis n. sp. et Alona ovata n. sp. (Crustacea, Cladocera), Cladoceres nouveaux du Venezuela. Ann Limnol - Int J Lim. 1986;22:219-29. doi:10.1051/limn/1986020.

65. Kotov AA. Structure of thoracic limbs in Bosminopsis deitersi Richard, 1895 (Anomopoda, Branchiopoda). Hydrobiologia. 1997;360:25-32. doi:10.1023/A:1003100701891.

66. Kotov AA, Ferrari FD. The taxonomic research of Jules Richard on Cladocera (Crustacea: Branchiopoda) and his collection at the National Museum of Natural History, USA. Zootaxa. 2010;2551:37-64. doi:10.11646/zootaxa.2551.1.2. 
67. Daday E von. Untersuchungen uber die Susswasser Mikrofauna Paraguays. Zoologica. 1905;44:1374.

68. Elias-Gutierrez M, Suarez Morales E, Gutierrez Aguirre M, Silva Briano M, Granados Ramirez JG, Garfias Espejo T. Cladocera y copepoda de las aguas continentales de Mexico: Guia ilustrada. Mexico City: Universidad Nacional Autonoma de Mexico; 2008.

69. Zernov SA. Note on zooplankton of rivers Shoshma and Vyatka Malmyzhskoho uezda Vyatskoj gubernii. Dnevnik Zoologicheskogo Otdeleniya Imperatorskogo Obshchestva Lubiteley Estestvoznaniya. Antropologii i Etnografii. 1901;3:4-36.

70. Meissner VI. Animal world of the Volga River near Saratov. Trudy Saratovskogo Obschestva Estestvoispitateley i Liubiteley Estestvoznaniya. 1902;3:1-70.

71. Meissner VI. Materials to the study of entomostracans of River Volga. Arbeiten der Biologishen Wolga-Station. 1903;1:159-201.

72. Zykoff W. Bosminopsis in Centralrussland. Zool Anz. 1906;30:22-4.

73. Song HH, Mizuno T. Composition and characteristics of plankton community in Lake Ok-Jeong. Bull Korean Fish Soc. 1982;15:333-44.

74. Yoon SM, Kim HS. A systematic study on the freshwater Cladocera from Korea. Korean J Syst Zool. 1987;3:175-207.

75. Kim IH. Key to the Korean freshwater Cladocera. Korean J Syst Zool. 1988;n.nspc.2:43-65.

76. Lieder U. Crustacea. Cladocera/Bosminidae. Susswasserfauna von Mitteleuropa. 1996;8:1-80.

77. Bledzki LA, Rybak JI. Freshwater Crustacean Zooplankton of Europe. Cham: Springer International Publishing; 2016.

78. Klocke E. Bosminopsis in Japan. Nebst Bemerkungen uber einige andere japanische Cladoceren und den Hakonesee. Annot Zool Jpn. 1903;4:123-35.

79. Werestchagin GY. On fauna of Cladocera of European Russia. Trudy gidrobiologicheskoy stantsii na Glubokom ozere. 1912;4:121-32.

80. Charleman NW. On some crustaceans of the Dniepr. Entomologicheskiy Vestnik. 1915;2:125-9.

81. Charleman NW. Bemerkung uber einige Crustaceen (Amphipoda und Cladocera) des Dnjepr. Russiche Hydrobiologisce Zeitschrift. 1922;1:322-4.

82. Vezhnovets VV. Crustaceans (Cladocera, Copepoda) in the water ecosystems of Belarus, a catalog and identification keys. Minsk: Belorusskaya Nauka; 2005.

83. Negrea S. Cladocera. In: Fauna Republicii Socialiste Romania. Volumul IV, CRUSTACEA. Fascicula 12. Bucuresti: Editura Academiei Republicii Socialiste Romania; 1983. pp. 1-399.

84. Skorikov AS, Bolokhontsev EN, Meissner VI. List of organisms found by Volga Biological Station in the area of its activity and identified to date (1900-1902). Ezhegodnik Volzhskoy Biologicheskoy Stantsii. 1903;1:20-47.

85. Skadowskiy SN. Some data on the biology of Bosminopsis zernowi Linko. Contributions to the studies of planknon of the Moscow River near Zvenigorod. Uchenije Zapiski Universiteta imeni A.L. 
Shaniavskogo. Trudy Biologicheskoy Laboratorii;1:1-62.

86. Greze BS. Microscopic fauna of the Volga River near Kostroma. Trudy Kostromskogo Nauchnogo Obschestva po Izucheniyu Mestnogo Kraya. 1921;27:3-12.

87. Greze BS. On the biology of oxbow lakes. 1. Zooplankton of lakes in valley of the Kostroma River. Trudy Kostromskogo Nauchnogo Obschestva po Izucheniyu Mestnogo Kraya. 1929;43:1-20.

88. Muraveisky SD. Uber das tierische Plankton des Flusses Kerschenetz. Arbeiten der Biologishen Wolga-Station. 1924;7:123-40.

89. Behning AL. Materials on the hydrofauna of the assessory sysmems of the Volga River. V. Material on the hydrofauna of the Kama. Trudy Volzhskoy Biologicjeskoy Stantsii. 1928;9:179-297.

90. Rylov VM. Vetvistousie rakoobraznie - Cladocerans (Cladocera). In: Zhadin VI, editor. Zhizn presnich vod. Moscow: Nauka; 1940. pp. 331-57.

91. Tarbeev ML, Golubeva AV, Tarasova AF, Shurganova GV. Evaluation of water quality in small and mirrle rivers of Nizhegorodskoe Povolzhje based on analysis of indicator species of zooplankton. Voda: Khinija i Ecologija. 2011;10:87-92.

92. Leschinskaya AS. Zooplankton and benthos of Obskaya Guba as a found source for the fish. Trudy Salekhardskogo Statsionara Uralskogo Otdeleniya AN USSR. 1962;2:1-76.

93. Werestchagin GY. The plankton of the Yamal Peninsula reservoirs. Annuaire du Musee Zoologique de I'Academie des. Sciences St-Petersburg. 1913;18:169-220.

94. Petlina AP, Yyrakova TV, Zalozniy NA, Bocharova TA, Lukjantseva LV, Podzhunas SS. Hydrobionts of small water currents of The Lower Tom Diver and their significance in the evaliation of the ecological state of water bodues. Sibirskii Ekolog Z. 2000;3:323-35.

95. Kukharskaya EV, Dolgin VN. Zooplankton of the Chulym River basin. Vestnik Tomskogo Gosudarstvennogo Universiteta. 2009;6:141-5.

96. Abramova EN, Zhulai IA. Appearance of new zooplankton species in water bodies of the Lena River delta. Tr Zool Inst Ross Akad Nauk. 2016;320:473-87. doi:10.31610/trudyzin/2016.320.4.473.

97. Afonina EY. Review of rotifers (Rotifera) and crustaceans (Cladocera, Calanoida, Cyclopoida, Harpacticoida) diversity in streams and lakes of the Upper Amur River Basin. Amurian zoological journal. 2013;5:248-55.

98. Cho KS, Mizuno T. Comparison of limnological conditions and plankton communities in the Uiam Lake consisting of the two different river systems. Korean J Limnol. 1977;10:73-85.

99. Ueno M. Cladocera of the Yangtze Delta. (Reports on the limnological survey of Central China. XXIII). J Shanghai Sci Inst. 1944;14:399-418.

100. Mashiko K. Cladocera and Rotatoria of Central China (Studies of the freshwater plankton of Central China, III). Sci Rep Kanazawa Univ. 1953;2:49-73.

101. Du Nan-shan. Cladocera of China. Peking: Science Press; 1973.

102. Xiang X-F, Ji G-H, Chen S-Z, Yu G-L, Xu L, Han B-P, et al. Annotated Checklist of Chinese Cladocera (Crustacea: Branchiopoda). Part I. Haplopoda, Ctenopoda, Onychopoda and Anomopoda. Zootaxa. 
2015;3904:1-27. doi:10.11646/zootaxa.3904.1.1. (families Daphniidae, Moinidae, Bosminidae, llyocryptidae).

103. Rane P. A new species of the genus Bosminopsis (Crustacea: Cladocera: Bosminidae) from India. J Bombay Nat Hist Soc. 1984;81:668-9.

104. Pascual JAF, Rizo EZC, Han BP, Dumont HJ, Papa RDS. Taxonomy and distribution of four Cladoceran families (Branchiopoda: Cladocera: Moinidae, Bosminidae, Chydoridae and Sididae) in Philippine inland waters. Raffles Bull Zool. 2014;62:771-94.

105. Fisher-Reid MC, Wiens JJ. What are the consequences of combining nuclear and mitochondrial data for phylogenetic analysis? Lessons from Plethodon salamanders and 13 other vertebrate clades. BMC Evol Biol. 2011;11:P300. doi:10.1186/1471-2148-11-300.

106. Hailer F, Kutschera VE, Hallström BM, Klassert D, Fain SR, Leonard JA, et al. Nuclear genomic sequences reveal that polar bears are an old and distinct bear lineage. Science. 2012;336:344-7. doi:10.1126/science.1216424.

107. Rosen DE. Vicariant Patterns and Historical Explanation in Biogeography. Syst Zool. 1978;27:15988. doi:10.2307/2412970.

108. Smirnov NN. Mesozoic Anomopoda (Crustacea) from Mongolia. Zool J Linn Soc. 1992;104:97-116. doi:10.1111/j.1096-3642.1992.tb00918.x.

109. Kotov AA, Korovchinsky NM. First record of fossil Mesozoic Ctenopoda (Crustacea, Cladocera). Zool J Linn Soc. 2006;146:269-74. doi:10.1111/j.1096-3642.2006.00204.x.

110. Kotov AA. Jurassic Cladocera (Crustacea, Branchiopoda) with a description of an extinct Mesozoic order. J Nat Hist. 2007;41:13-37. doi:10.1080/00222930601164445.

111. Kotov AA, Taylor DJ. Mesozoic fossils (145 Mya) suggest the antiquity of the subgenera of Daphnia and their coevolution with chaoborid predators. BMC Evol Biol. 2011;11:129. doi:10.1186/1471-214811-129.

112. Liao H-Y, Cai C-Y, Shen Y-B, Sun X-Y, Huang D-Y. An Early Cretaceous branchiopod community in northeastern China: Discovery of daphniid (Cladocera: Anmopoda) ephippia in the early assemblage of the Jehol Biota. Cretac Res. 2020;113:104491. doi:10.1016/j.cretres.2020.104491.

113. Anderson LI, Crighton WRB, Hass H. A new univalve crustacean from the Early Devonian Rhynie chert hot-spring complex. Trans R Soc Edinburgh: Earth Sci. 2004;94:355-69. doi:10.1017/S0263593300000742.

114. Womack T, Slater BJ, Stevens LG, Anderson LI, Hilton J. First cladoceran fossils from the Carboniferous: Palaeoenvironmental and evolutionary implications. Palaeogeogr Palaeoclimatol Palaeoecol. 2012;344-345:39-48. doi:10.1016/j.palaeo.2012.05.012.

115. Sacherova V, Hebert PDN. The evolutionary history of the Chydoridae (Crustacea: Cladocera). Biol J Linn Soc. 2003;79:629-43. doi:10.1046/j.1095-8312.2003.00216.x.

116. Schwentner M, Clavier S, Fritsch M, Olesen J, Padhye S, Timms BV, Richter S. Cyclestheria hislopi (Crustacea: Branchiopoda): a group of morphologically cryptic species with origins in the Cretaceous. Mol Phylogenet Evol. 2013;66:800-10. doi:10.1016/j.ympev.2012.11.005. 
117. Cornetti L, Fields PD, van Damme K, Ebert D. A fossil-calibrated phylogenomic analysis of Daphnia and the Daphniidae. Mol Phylogenet Evol. 2019;137:250-62. doi:10.1016/j.ympev.2019.05.018.

118. Kotov AA. Morphology and phylogeny of the Anomopoda (Crustacea: Cladocera). Moscow: KMK Scientific press Ltd.; 2013.

119. Austin TS. The fossil species of Bosmina, App. 1 of Studies on Connecticut Lake sediments. Am J Sci. 1942;240:325-31. doi:10.2475/ajs.240.5.325.

120. Hofmann W. Postglacial morphological variation in Bosmina longispina Leydig (Crustacea, Cladocera) from the Grober Ploner See (north Germany) and its taxonomic implications. J Zoolog Syst Evol Res. 1984;22:294-301. doi:10.1111/j.1439-0469.1984.tb00664.x.

121. Korovchinsky NM. The Cladocera (Crustacea: Branchiopoda) as a relict group. Zool J Linn Soc. 2006;147:109-24. doi:10.1111/j.1096-3642.2006.00217.x.

122. Hewitt G. The genetic legacy of the Quaternary ice ages. Nature. 2000;405:907-13. doi:10.1038/35016000.

123. Taylor DJ, Finston TL, Hebert PDN. Biogeography of a widespread freshwater crustacean: Pseudocongruence and cryptic endemism in the North American Daphnia laevis complex. Evolution. 1998;52:1648-70. doi:10.1111/j.1558-5646.1998.tb02245.x.

124. Cox AJ, Hebert PDN. Colonization, extinction, and phylogeographic patterning in a freshwater crustacean. Mol Ecol. 2001;10:371-86. doi:10.1046/j.1365-294X.2001.01188.x.

125. Darwin C. On the Origin of Species by means of Natural Selection, or the preservation of favoured races in the struggle for life. London: John Murray; 1859.

126. Casane D, Laurenti P. Why coelacanths are not 'living fossils': a review of molecular and morphological data. Bioessays. 2013;35:332-8. doi:10.1002/bies.201200145.

127. Pennak RW. Fresh-water invertebrates of the United States. New York: The Ronald Press Company; 1953.

128. Mergeay J, Aguilera X, Declerck S, Petrusek A, Huyse T, Meester L de. The genetic legacy of polyploid Bolivian Daphnia: the tropical Andes as a source for the North and South American D. pulicaria complex. Mol Ecol. 2008;17:1789-800. doi:10.1111/j.1365-294X.2007.03679.x.

129. Daday E von. Adatok Nemet-Kelet-Afrika edesvizi mikrofaunajanak iameretehez. Mathematikai es Termeszettudomanyi Ertesito. Budapest. 1908;26:(1):1-42, 43-57; (2): 200-220; (3): 294-321; (4): 374-404, 405-421; (5): 455-474.

130. Popova EV, Petrusek A, Kořínek V, Mergeay J, Bekker El, Karabanov DP, et al. Revision of the Old World Daphnia (Ctenodaphnia) similis group (Cladocera: Daphniidae). Zootaxa. 2016;4161:1-40. doi:10.11646/zootaxa.4161.1.1.

131. Sinev AY, Karabanov DP, Kotov AA. A new North Eurasian species of the Alona affinis complex (Cladocera: Chydoridae). Zootaxa. 2020;4767:115-37. doi:10.11646/zootaxa.4767.1.5.

132. Rogers DC, Kotov AA, Sinev AY, Glagolev SM, Korovchinsky NM, Smirnov NN, Bekker El. Chapter 16.2. Arthropoda: Class Branchiopoda. In: Rogers CD, Thorp JH, editors. Thorp and Covich's Freshwater 
Invertebrates. Volume 4: Keys to Palaearctic Fauna. London: Academic Press; 2019. pp. 643-724. doi:10.1016/B978-0-12-385024-9.00018-6.

133. Hebert PDN, Cywinska A, Ball SL, deWaard JR. Biological identifications through DNA barcodes. Proc R Soc Lond B Biol Sci. 2003;270:313-21. doi:10.1098/rspb.2002.2218.

134. Yang L, Tan Z, Wang D, Xue L, Guan M-X, Huang T, Li R. Species identification through mitochondrial rRNA genetic analysis. Sci Rep. 2014;4:4089. doi:10.1038/srep04089.

135. Hovmoller R, Pape T, Kallersjo M. The Palaeoptera problem: basal Pterygote phylogeny inferred from $18 S$ and 28S rDNA sequences. Cladistics. 2002;18:313-23. doi:10.1111/j.10960031.2002.tb00153.x.

136. Karabanov DP, Bekker El, Shiel RJ, Kotov AA. Invasion of a Holarctic planktonic cladoceran Daphnia galeata Sars (Crustacea: Cladocera) in the Lower Lakes of South Australia. Zootaxa. 2018;4402:136-48. doi:10.11646/zootaxa.4402.1.6.

137. Boratyn GM, Camacho C, Cooper PS, Coulouris G, Fong A, Ma N, et al. BLAST: a more efficient report with usability improvements. Nucleic Acids Res. 2013;41:W29-33. doi:10.1093/nar/gkt282.

138. Chapco W, Kuperus WR, Litzenberger G. Molecular phylogeny of Melanopline Grasshoppers (Orthoptera: Acrididae): the genus Melanoplus. Ann Entomol Soc Am. 1999;92:617-23. doi:10.1093/aesa/92.5.617.

139. Reumont BM von, Meusemann K, Szucsich NU, Dell'Ampio E, Gowri-Shankar V, Bartel D, et al. Can comprehensive background knowledge be incorporated into substitution models to improve phylogenetic analyses? A case study on major arthropod relationships. BMC Evol Biol. 2009;9:119. doi:10.1186/1471-2148-9-119.

140. Nei M, Kumar S. Molecular evolution and phylogenetics. New York: Oxford University Press; 2000.

141. Rozas J, Ferrer-Mata A, Sanchez-DelBarrio JC, Guirao-Rico S, Librado P, Ramos-Onsins SE, SanchezGracia A. DnaSP 6: DNA sequence polymorphism analysis of large data sets. Mol Biol Evol. 2017;34:3299-302. doi:10.1093/molbev/msx248.

142. Ramirez-Soriano A, Ramos-Onsins SE, Rozas J, Calafell F, Navarro A. Statistical power analysis of neutrality tests under demographic expansions, contractions and bottlenecks with recombination. Genetics. 2008;179:555-67. doi:10.1534/genetics.107.083006.

143. Garrigan D, Lewontin R, Wakeley J. Measuring the sensitivity of single-locus "neutrality tests" using a direct perturbation approach. Mol Biol Evol. 2010;27:73-89. doi:10.1093/molbev/msp209.

144. Watterson GA. On the number of segregating sites in genetical models without recombination. Theor Popul Biol. 1975;7:256-76. doi:10.1016/0040-5809(75)90020-9.

145. Katoh K, Rozewicki J, Yamada KD. MAFFT online service: Multiple sequence alignment, interactive sequence choice and visualization. Brief Bioinformatics. 2019;20:1160-6. doi:10.1093/bib/bbx108.

146. Vaidya G, Lohman DJ, Meier R. SequenceMatrix. Concatenation software for the fast assembly of multi-gene datasets with character set and codon information. Cladistics. 2011;27:171-80. doi:10.1111/j.1096-0031.2010.00329.x. 
147. Kalyaanamoorthy S, Minh BQ, Wong TKF, Haeseler A von, Jermiin LS. ModelFinder: Fast model selection for accurate phylogenetic estimates. Nat Methods. 2017;14:587-9.

doi:10.1038/nmeth.4285.

148. Trifinopoulos J, Nguyen L-T, Haeseler A von, Minh BQ. W-IQ-TREE: a fast online phylogenetic tool for maximum likelihood analysis. Nucleic Acids Res. 2016;44:W232-5. doi:10.1093/nar/gkw256.

149. Schwarz G. Estimating the dimension of a model. Ann Stat. 1978;6:461-4. doi:10.1214/aos/1176344136.

150. Heled J, Drummond AJ. Bayesian inference of species trees from multilocus data. Mol Biol Evol. 2010;27:570-80. doi:10.1093/molbev/msp274.

151. Chernomor O, Haeseler A von, Minh BQ. Terrace aware data structure for phylogenomic inference from supermatrices. Syst Biol. 2016;65:997-1008. doi:10.1093/sysbio/syw037.

152. Molloy EK, Warnow T. To include or not to include: The impact of gene filtering on species tree estimation methods. Syst Biol. 2018;67:285-303. doi:10.1093/sysbio/syx077.

153. Nguyen L-T, Schmidt HA, Haeseler A von, Minh BQ. IQ-TREE: A fast and effective stochastic algorithm for estimating maximum-likelihood phylogenies. Mol Biol Evol. 2015;32:268-74.

doi:10.1093/molbev/msu300.

154. Hoang DT, Chernomor O, Haeseler A von, Minh BQ, Le Vinh S. UFBoot2: Improving the ultrafast bootstrap approximation. Mol Biol Evol. 2018;35:518-22. doi:10.1093/molbev/msx281.

155. Shimodaira H. An approximately unbiased test of phylogenetic tree selection. Syst Biol. 2002;51:492-508. doi:10.1080/10635150290069913.

156. Okonechnikov K, Golosova O, Fursov M. Unipro UGENE: a unified bioinformatics toolkit. Bioinformatics. 2012;28:1166-7. doi:10.1093/bioinformatics/bts091.

157. Bouckaert R, Vaughan TG, Barido-Sottani J, Duchene S, Fourment M, Gavryushkina A, et al. BEAST 2.5: An advanced software platform for Bayesian evolutionary analysis. PLoS Comput Biol. 2019;15:e1006650. doi:10.1371/journal.pcbi.1006650.

158. Drummond AJ, Suchard MA, Xie D, Rambaut A. Bayesian phylogenetics with BEAUti and the BEAST 1.7. Mol Biol Evol. 2012;29:1969-73. doi:10.1093/molbev/mss075.

159. Rambaut A, Drummond AJ, Xie D, Baele G, Suchard MA. Posterior summarization in Bayesian phylogenetics using Tracer 1.7. Syst Biol. 2018;67:901-4. doi:10.1093/sysbio/syy032.

160. Leigh JW, Bryant D, Nakagawa S. POPART: full-feature software for haplotype network construction. Methods Ecol Evol. 2015;6:1110-6. doi:10.1111/2041-210X.12410.

161. Carstens BC, Pelletier TA, Reid NM, Satler JD. How to fail at species delimitation. Mol Ecol. 2013;22:4369-83. doi:10.1111/mec.12413.

162. Pons J, Barraclough TG, Gomez-Zurita J, Cardoso A, Duran DP, Hazell S, et al. Sequence-based species delimitation for the DNA taxonomy of undescribed insects. Syst Biol. 2006;55:595-609. doi:10.1080/10635150600852011.

163. 10.1093 /sysbio/syp039

Page 34/51 
Lohse K. Can mtDNA barcodes be used to delimit species? A response to Pons et al. (2006). Syst Biol. 2009;58:439 - 42; discussion 442-4. doi:10.1093/sysbio/syp039.

164. Reid NM, Carstens BC. Phylogenetic estimation error can decrease the accuracy of species delimitation: a Bayesian implementation of the general mixed Yule-coalescent model. BMC Evol Biol. 2012;12:196. doi:10.1186/1471-2148-12-196.

165. Sweet AD, Boyd BM, Allen JM, Villa SM, Valim MP, Rivera-Parra JL, et al. Integrating phylogenomic and population genomic patterns in avian lice provides a more complete picture of parasite evolution. Evolution. 2018;72:95-112. doi:10.1111/evo.13386.

166. Kapli P, Lutteropp S, Zhang J, Kobert K, Pavlidis P, Stamatakis A, Flouri T. Multi-rate Poisson tree processes for single-locus species delimitation under maximum likelihood and Markov chain Monte Carlo. Bioinformatics. 2017;33:1630-8. doi:10.1093/bioinformatics/btx025.

167. Zhang J, Kapli P, Pavlidis P, Stamatakis A. A general species delimitation method with applications to phylogenetic placements. Bioinformatics. 2013;29:2869-76. doi:10.1093/bioinformatics/btt499.

168. Drummond AJ, Bouckaert RR. Bayesian evolutionary analysis with BEAST2. Cambridge: Cambridge University Press; 2015.

169. Knowlton N, Weigt LA. New dates and new rates for divergence across the Isthmus of Panama. Proc R Soc Lond B Biol Sci. 1998;265:2257-63. doi:10.1098/rspb.1998.0568.

170. Schubart CD, Diesel R, Hedges SB. Rapid evolution to terrestrial life in Jamaican crabs. Nature. 1998;393:363-5. doi:10.1038/30724.

171. Schwartz JH, Maresca B. Do molecular clocks run at all? A critique of molecular systematics. Biol Theory. 2006;1:357-71. doi:10.1162/biot.2006.1.4.357.

172. Suchard MA, Lemey P, Baele G, Ayres DL, Drummond AJ, Rambaut A. Bayesian phylogenetic and phylodynamic data integration using BEAST 1.10. Virus Evol. 2018;4:vey016. doi:10.1093/ve/vey016.

173. Gernhard T. The conditioned reconstructed process. J Theor Biol. 2008;253:769-78. doi:10.1016/j.jtbi.2008.04.005.

174. Barido-Sottani J, Boskova V, Du Plessis L, Kuhnert D, Magnus C, Mitov V, et al. Taming the BEAST - a community teaching material resource for BEAST2. Syst Biol. 2018;67:170-4. doi:10.1093/sysbio/syx060.

175. Matzke NJ. Probabilistic historical biogeography: New models for founder-event speciation, imperfect detection, and fossils allow improved accuracy and model-testing. Front Biogeogr. 2013;5:242-8. doi:10.21425/F5FBG19694.

176. Yu Y, Harris AJ, Blair C, He X. RASP (Reconstruct Ancestral State in Phylogenies): A tool for historical biogeography. Mol Phylogenet Evol. 2015;87:46-9. doi:10.1016/j.ympev.2015.03.008.

177. Matzke NJ. Model selection in historical biogeography reveals that founder-event speciation is a crucial process in Island Clades. Syst Biol. 2014;63:951-70. doi:10.1093/sysbio/syu056. 
178. Clark JR, Ree RH, Alfaro ME, King MG, Wagner WL, Roalson EH. A comparative study in ancestral range reconstruction methods: retracing the uncertain histories of insular lineages. Syst Biol. 2008;57:693-707. doi:10.1080/10635150802426473.

179. Muller RD, Cannon J, Qin X, Watson RJ, Gurnis M, Williams S, et al. GPlates: building a virtual Earth through deep time. Geochem Geophys Geosyst. 2018;19:2243-61. doi:10.1029/2018GC007584.

\section{Figures}

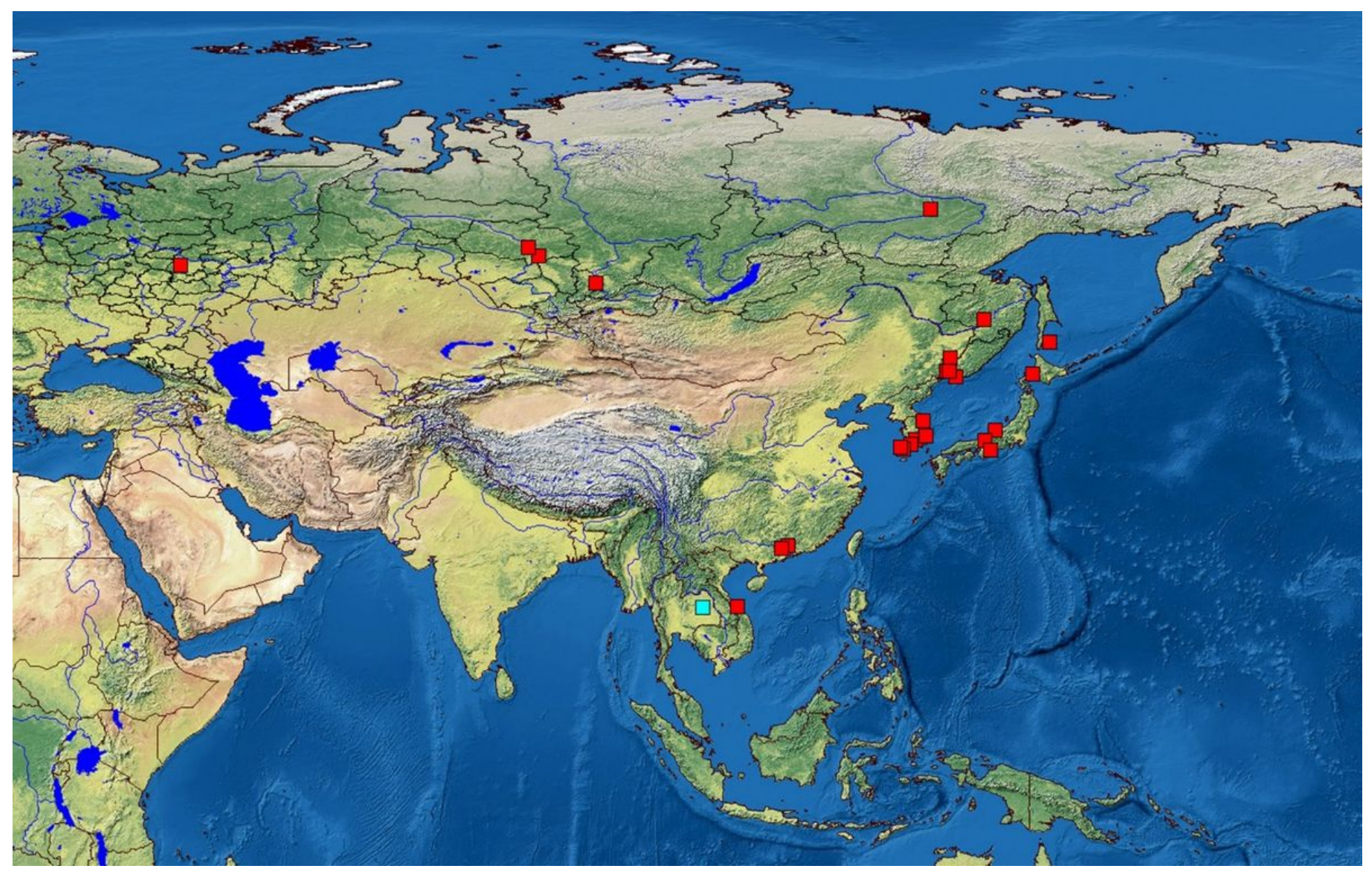

\section{Figure 1}

Distribution of studies populations of Bosminopsis deitersi group belonged to two major phylogroups: B. zernowi (red rectangles) and Bosminopsis sp. (blue rectangle). Visualisation of the localities was made in DIVA-GIS7.5.0 (https://www.diva-gis.org) using free spatial GIS data from

http://www.naturalearthdata.com as the layers. Note: The designations employed and the presentation of the material on this map do not imply the expression of any opinion whatsoever on the part of Research Square concerning the legal status of any country, territory, city or area or of its authorities, or concerning the delimitation of its frontiers or boundaries. This map has been provided by the authors. 


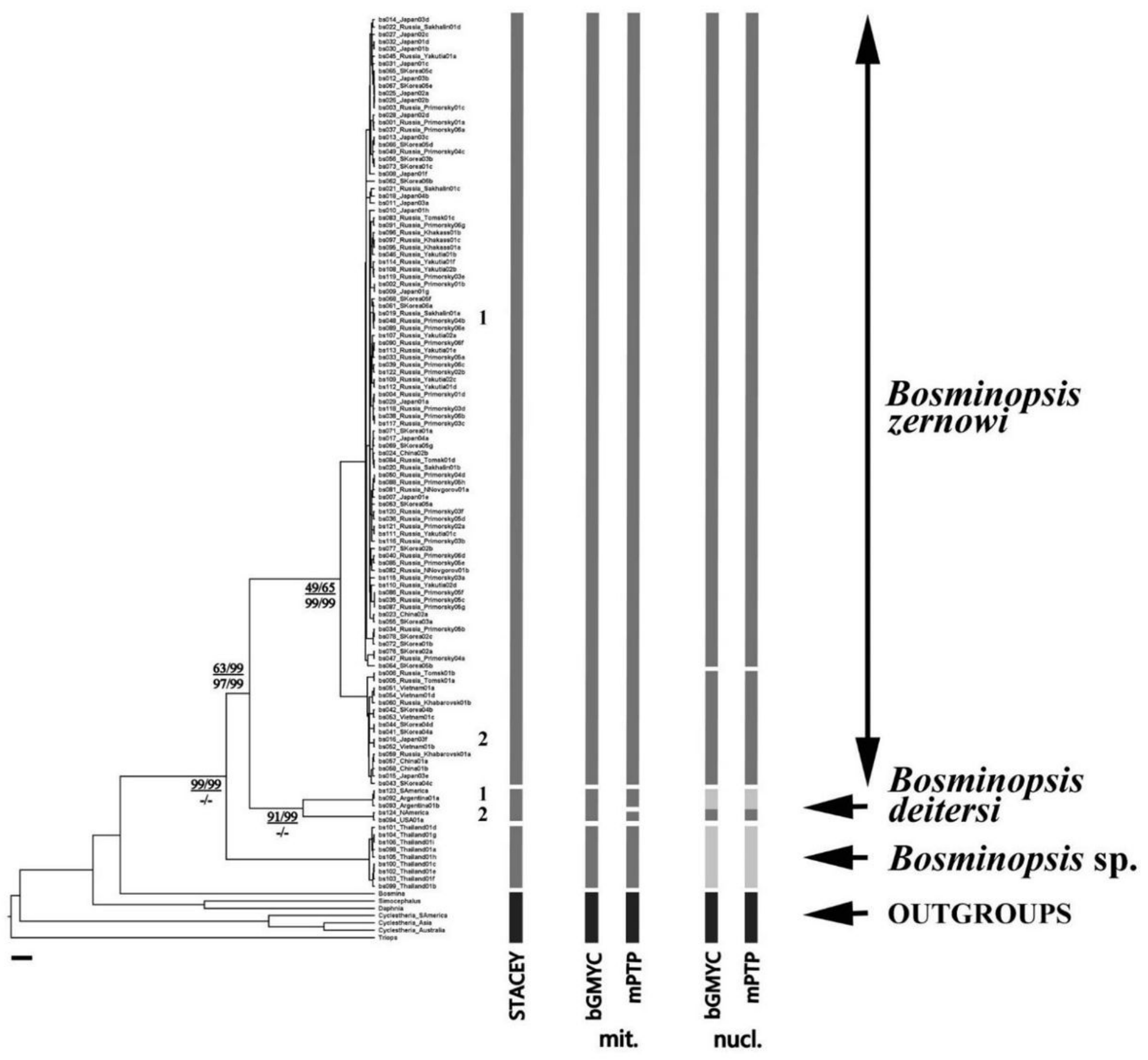

Figure 2

BI multi-locus tree based on the $\mathrm{COI}+16 \mathrm{~S}+18 \mathrm{~S}+28 \mathrm{~S}$ sequences, with a summary of results of the cybertaxonomic species delimitation by different methods. Analyses referring are based on mitochondrial (mit.), nuclear (nuc.) and multi-locus datasets (STACEY). Node supports are: UFboot2 (ML) and posterior probabilities (BI), in percent for mitochondrial genes in the numerator and nuclear genes in the denominator. 


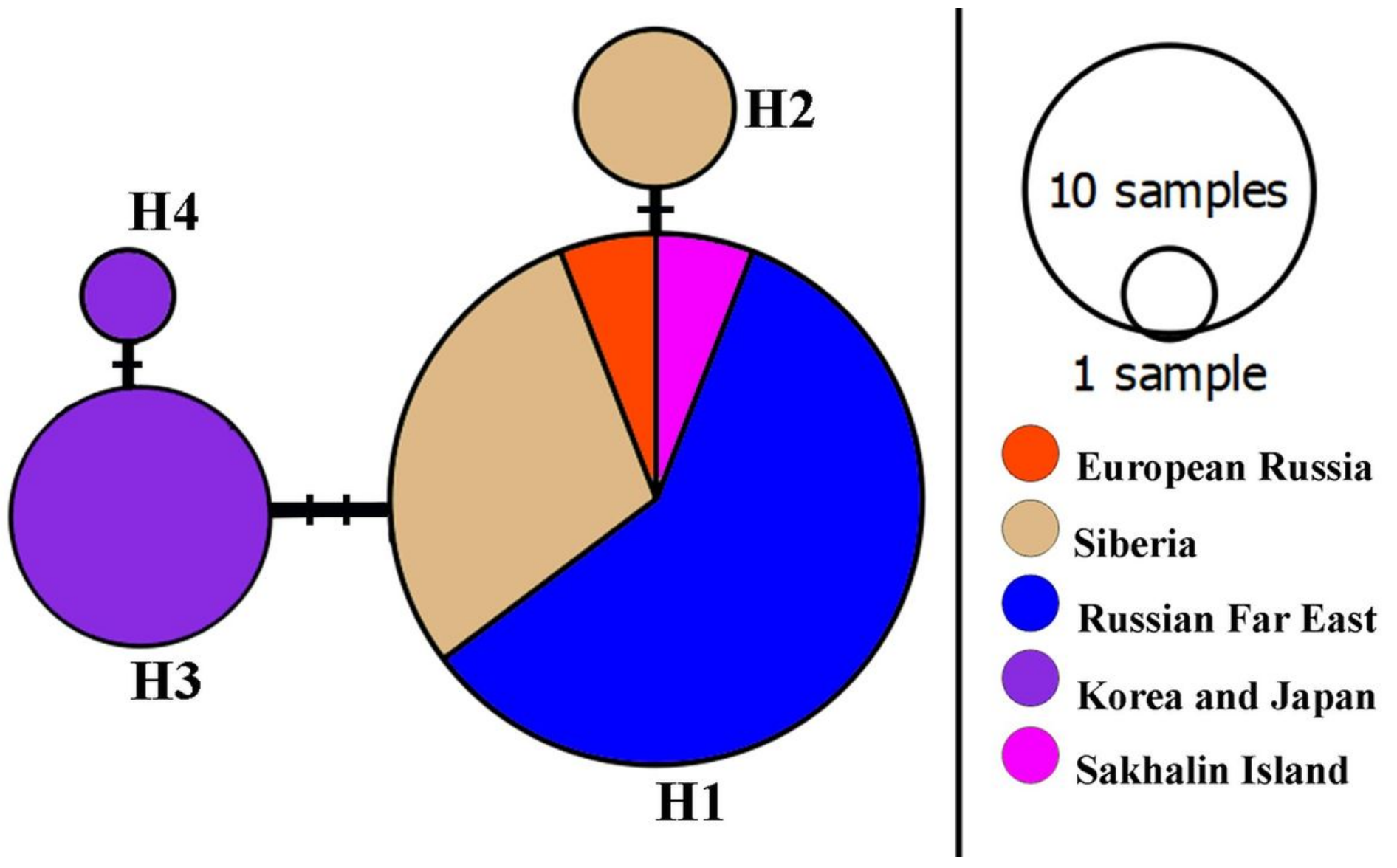

Figure 3

A haplotype 16S network for Bosminopsis zernowi. 

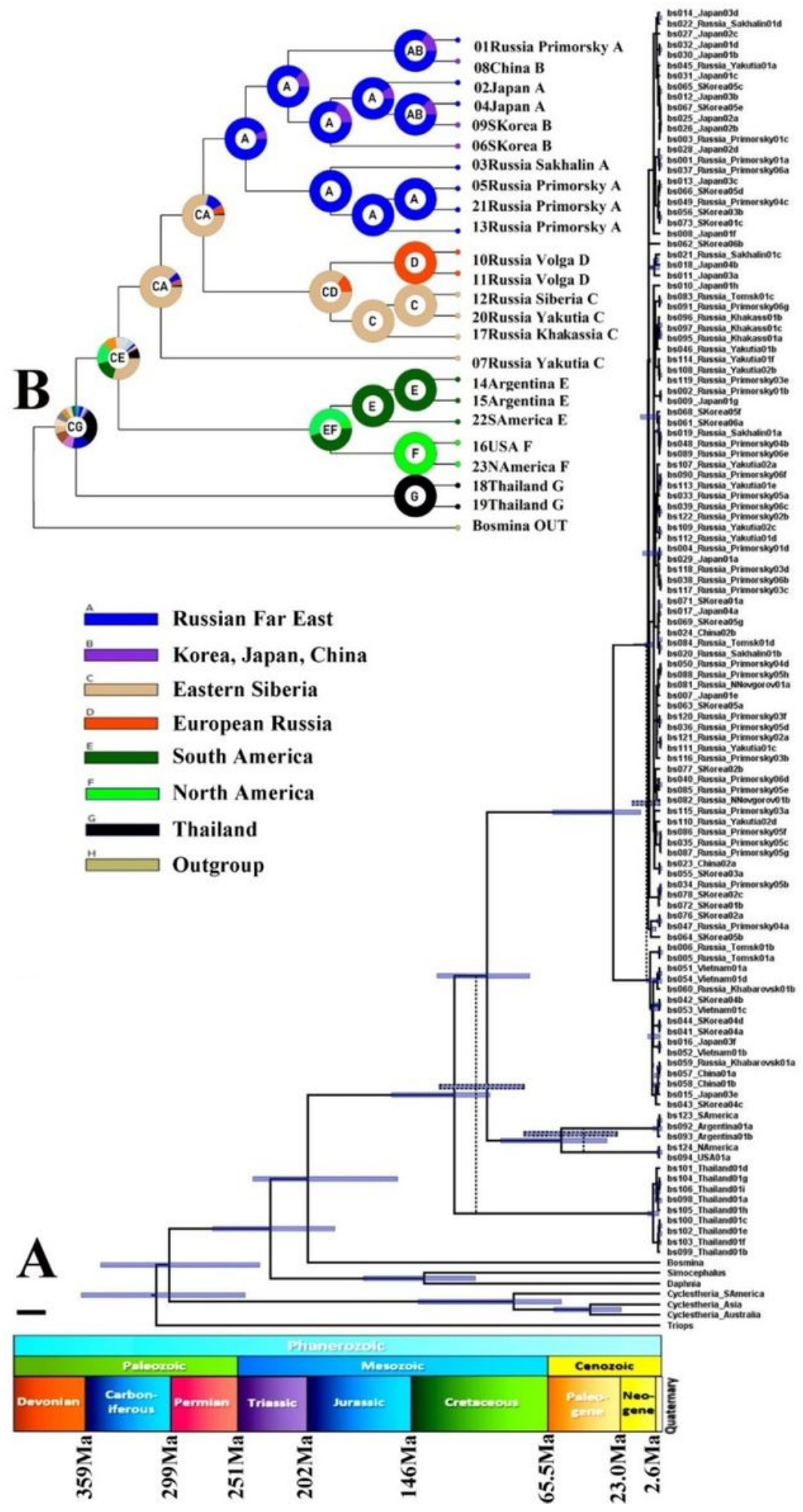
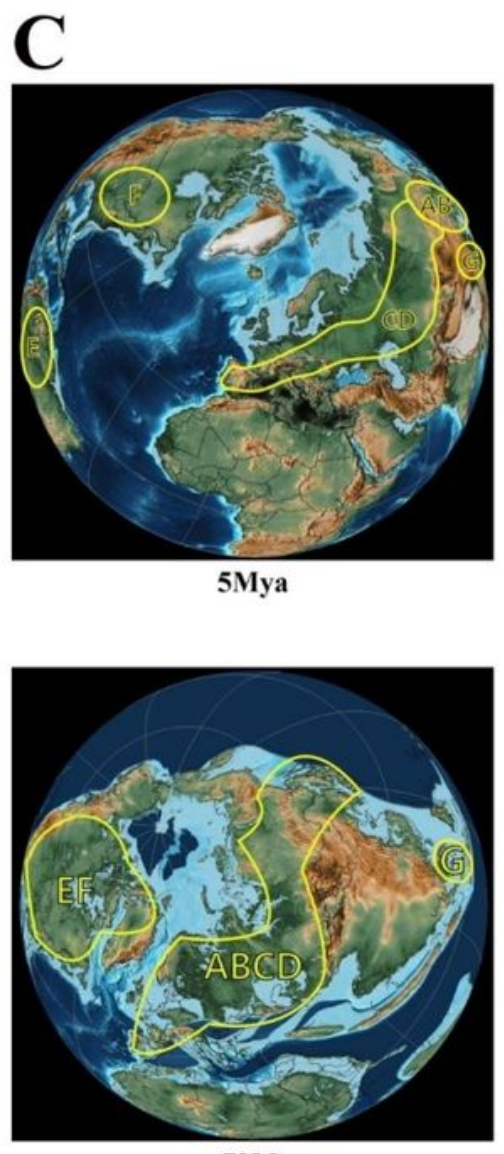

72Mya

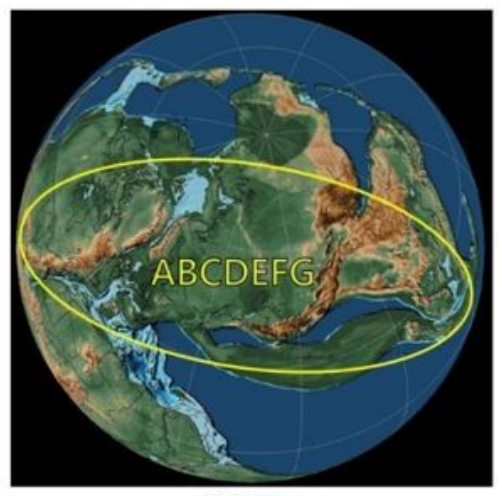

198Mya

Figure 4

Biogeographic history of B. deitersi group. A - A possible phylogenetic tree for four loci based on the strict molecular clock, speciation by Yule process. Alternative topology of mitochondrial tree is represented by dotted line. Stratigraphic chart according to the International Commission on Stratigraphy (2020). B - A proposed biogeographic history of the B. deitersi group on the consensus mitochondrial tree combined with the result of DIVALAKE+J model. Only tree topology is represented. Pie charts in each 
node demonstrate probabilities of alternative ancestral ranges; the most probable range is marked by the letter in the center. $\mathrm{C}$ - Possible ancestral ranges on palaeo-maps are represented at: 198 MYA, 72 MYA and 5 MYA. The maps are from the PalaeoAtlas for GPlates under General Public License (GPL) Ver. 2.

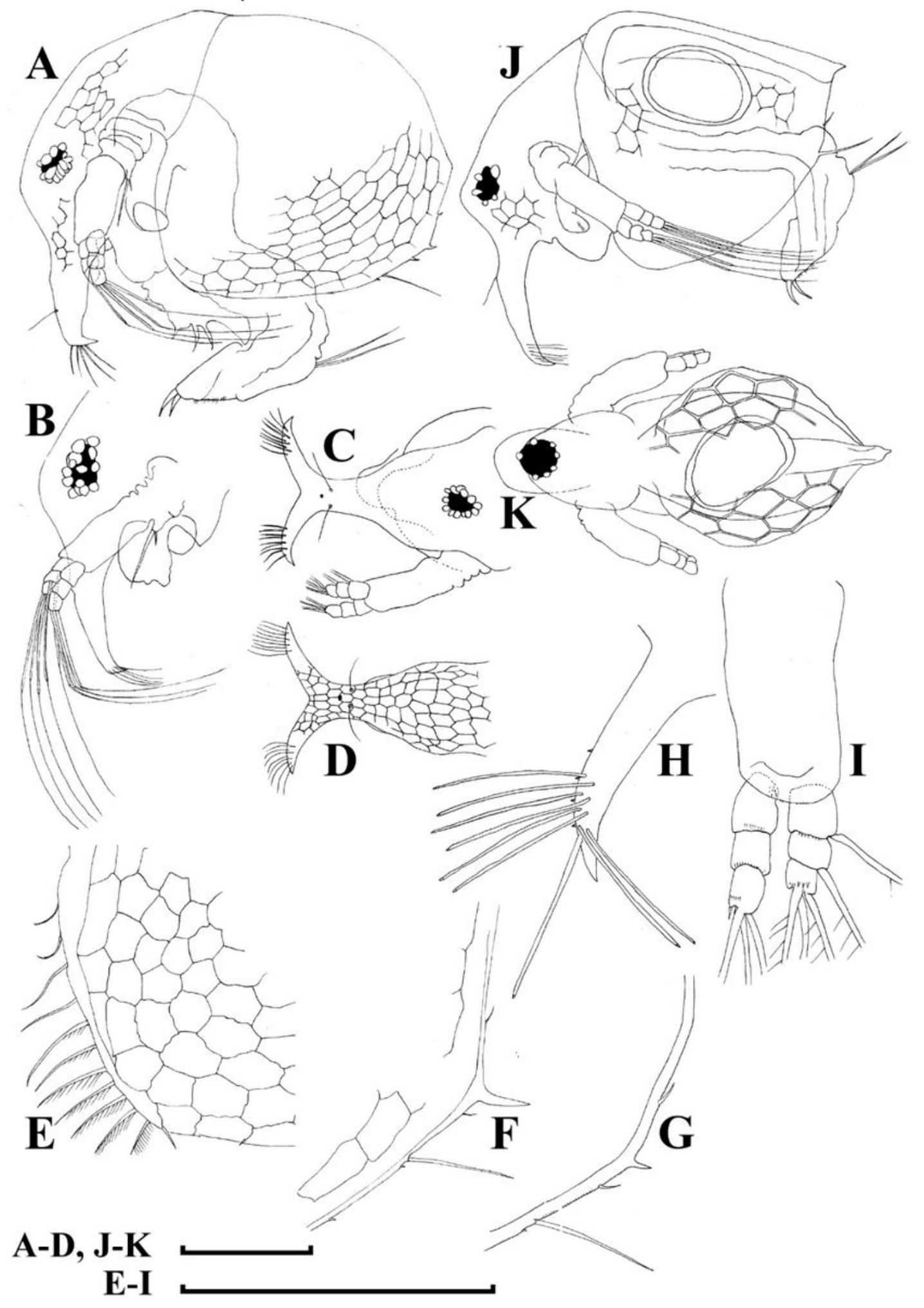

Figure 5

Bosminopsis deitersi Richard, 1895 from Rio Xingu (A), Lago do Castanho (B-D), Rio Tapajos (E) in Amazonia, Brazil, South America (A-E) and Bosminopsis sp. from Bung Pueng, Kalasin Province (F) and 
Lake Bueng Khong Long, Nong Khai Province $(\mathrm{G}-\mathrm{H})$ in Thailand $(\mathrm{F}-\mathrm{H})$. A, Adult parthenogenetic female. B-D, Ephippial female, lateral, dorsal and anterior view. E, Juvenile female. F. Large adult parthenogenetic female. $\mathrm{G}-\mathrm{H}$, Juvenile female and its mucro. Scale bars: $A-G=0.1 \mathrm{~mm}, \mathrm{H}=0.01 \mathrm{~mm}$.

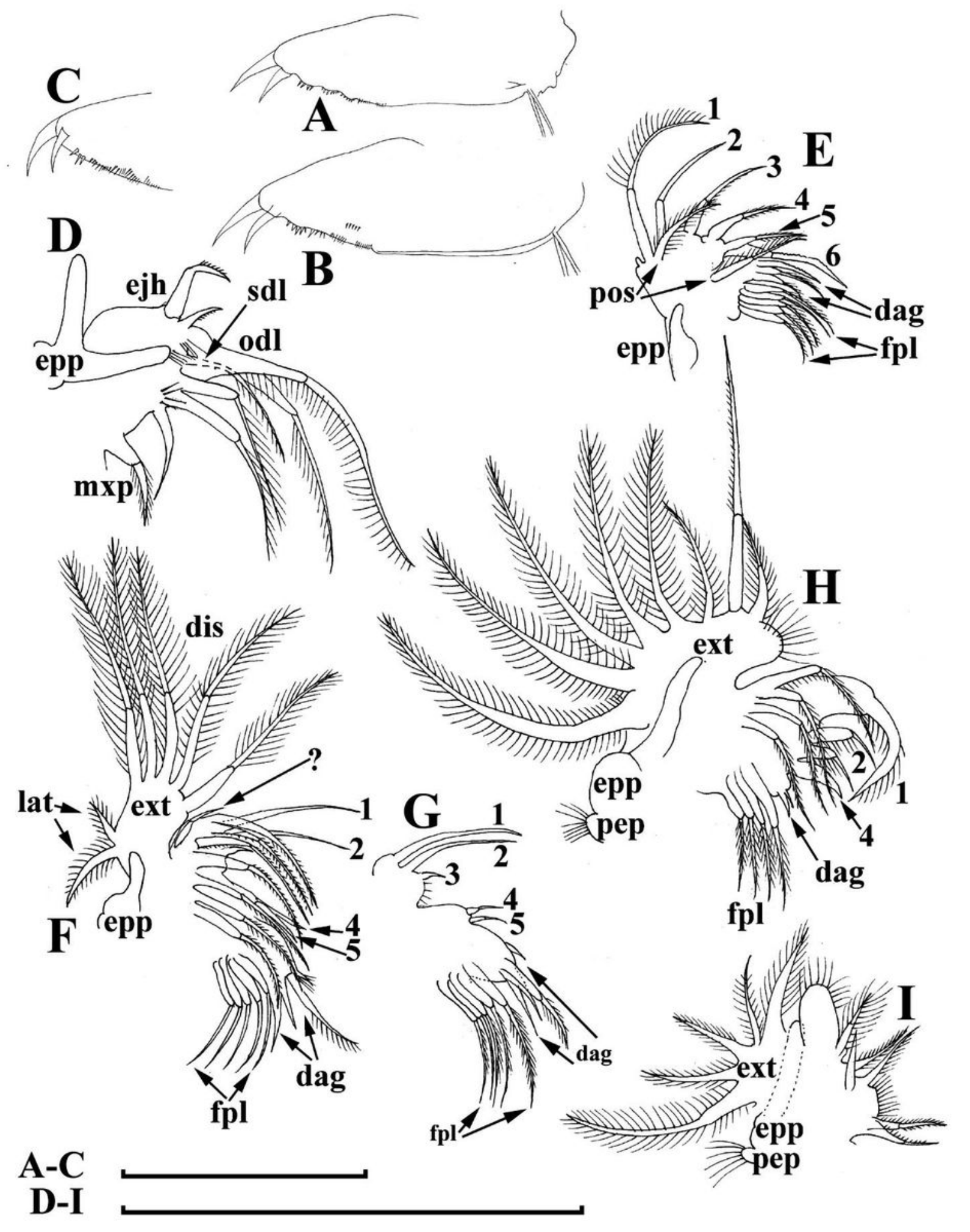

Figure 6

Bosminopsis deitersi Richard, 1895, parthenogenetic (A-I) and ephippial (J-K) females from Lago do Castanho and Lago Cristalino, both in Amazonas, Brazil. A, Adult parthenogenetic female, lateral view. B, 
Its head, lateral view. C-D, Head, anterior view. E, Postero-ventral portion of valve. F-G, Posteroventral portion of valve. H, Antenna I. I, Antenna II. J, Mature ephippial female, lateral view. K, Mature ephippial female, dorsal view. Scale bars $=0.1 \mathrm{~mm}$.

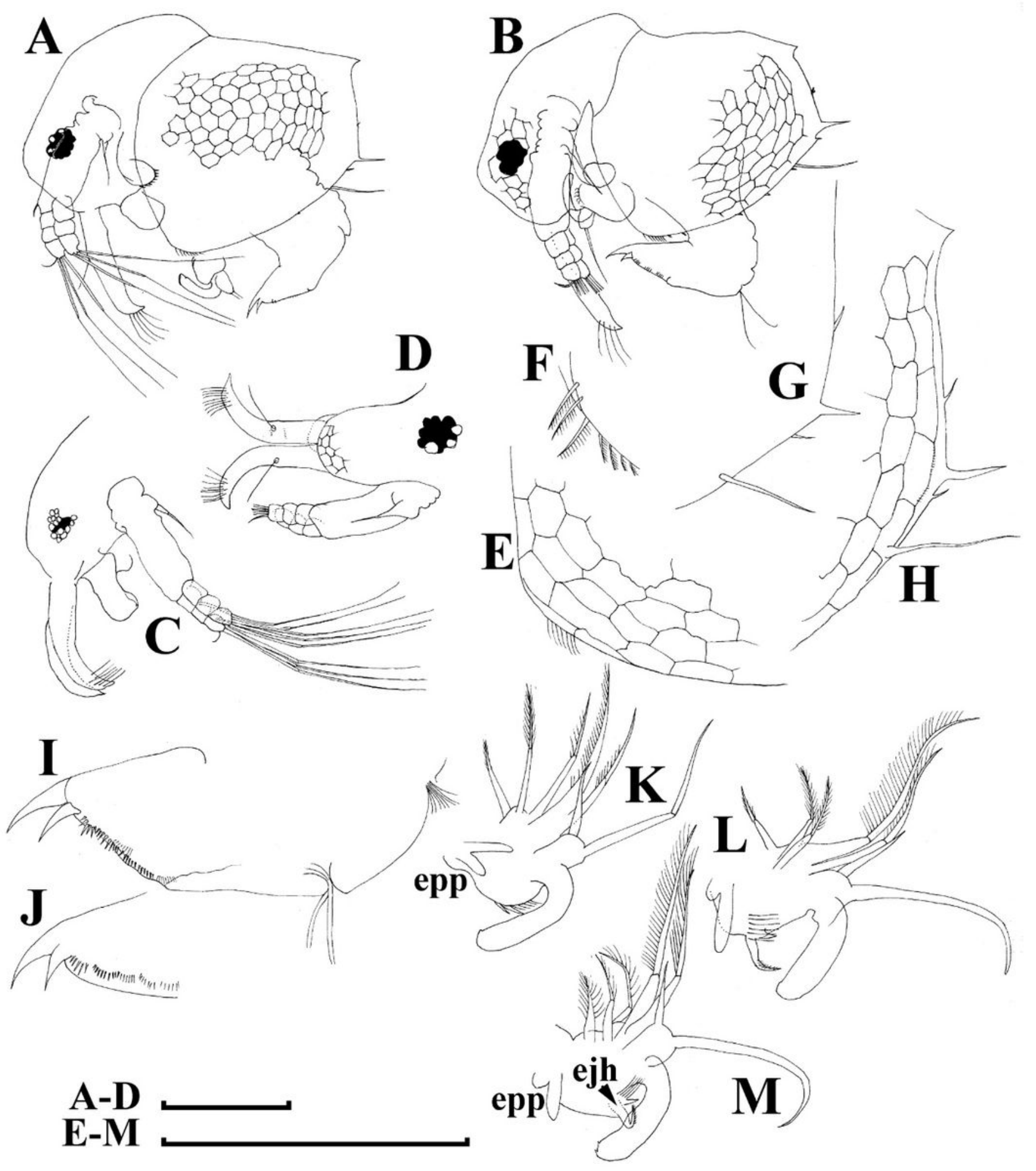

Figure 7

Bosminopsis deitersi Richard, 1895, parthenogenetic female from Lago do Castanho, Amazonas, Brazil. A-C, Postabdomen, lateral view. D, Limb I. E, Limb II. F, Limb III. G, Gnathobase of limb III. H, Limb IV. I, 
Limb V. Scale bar $=0.1 \mathrm{~mm}$.

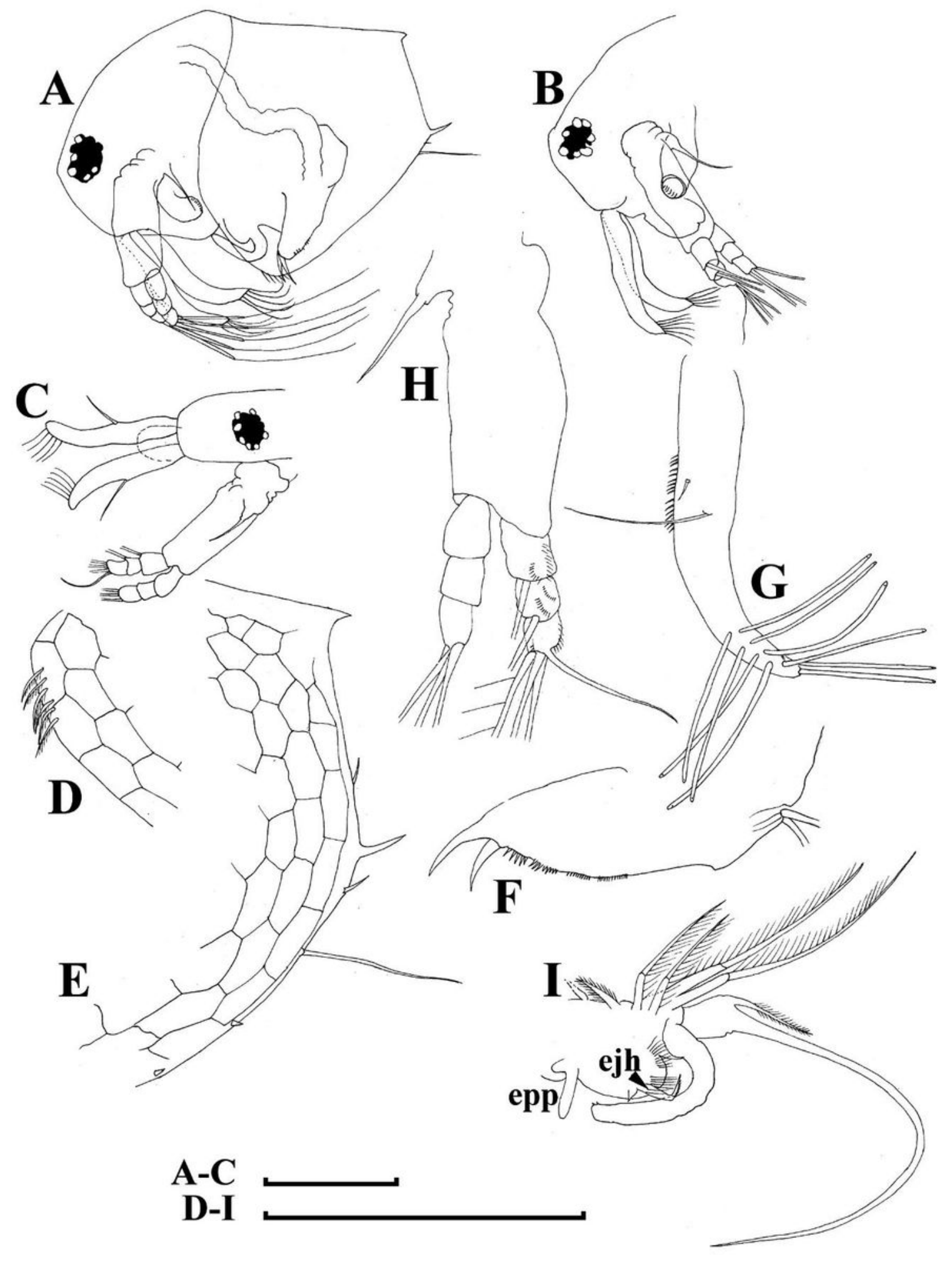

Figure 8

Bosminopsis deitersi Richard, 1895, juvenile male from Lago do Castanho (Amazonas, Brazil). A-B, Lateral view. C, Head, lateral view. D, Head, anterior view. E-F, Antero-ventral portion of valve. G-H, Postero-ventral portion of valve. I-J, Postabdomen. K-M, Limb I. Scale bars $=0.1 \mathrm{~mm}$. 

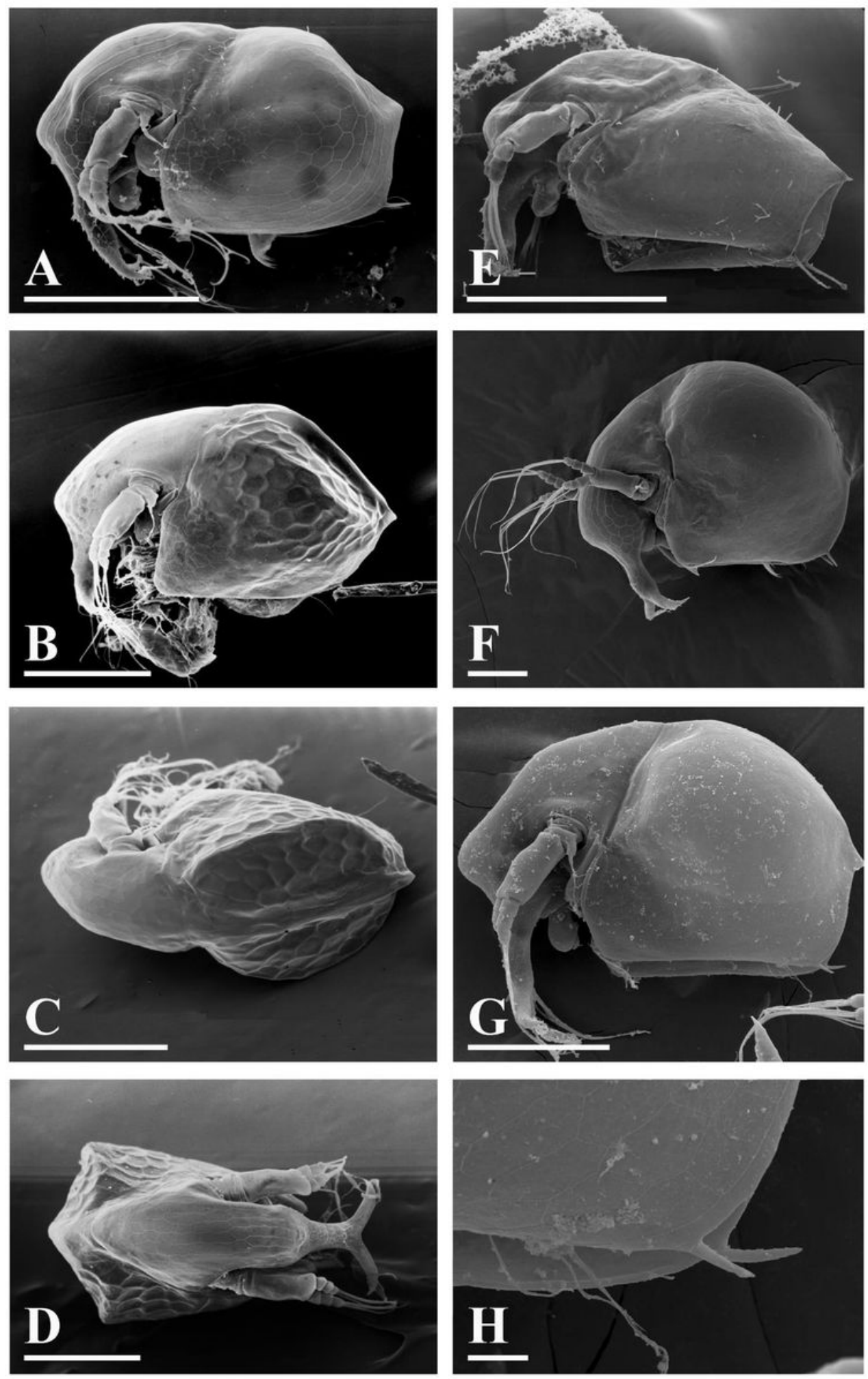

\section{Figure 9}

Bosminopsis deitersi Richard, 1895, adult male from Lago do Castanho, Amazonas, Brazil. A-B, Lateral view. C, head, anterior view. D, Antero-ventral portion of valve. E, Postero-ventral portion of valve. F, Postabdomen. G, Antenna I. H, Antenna II. I, Limb I. Scale bars $=0.1 \mathrm{~mm}$. 

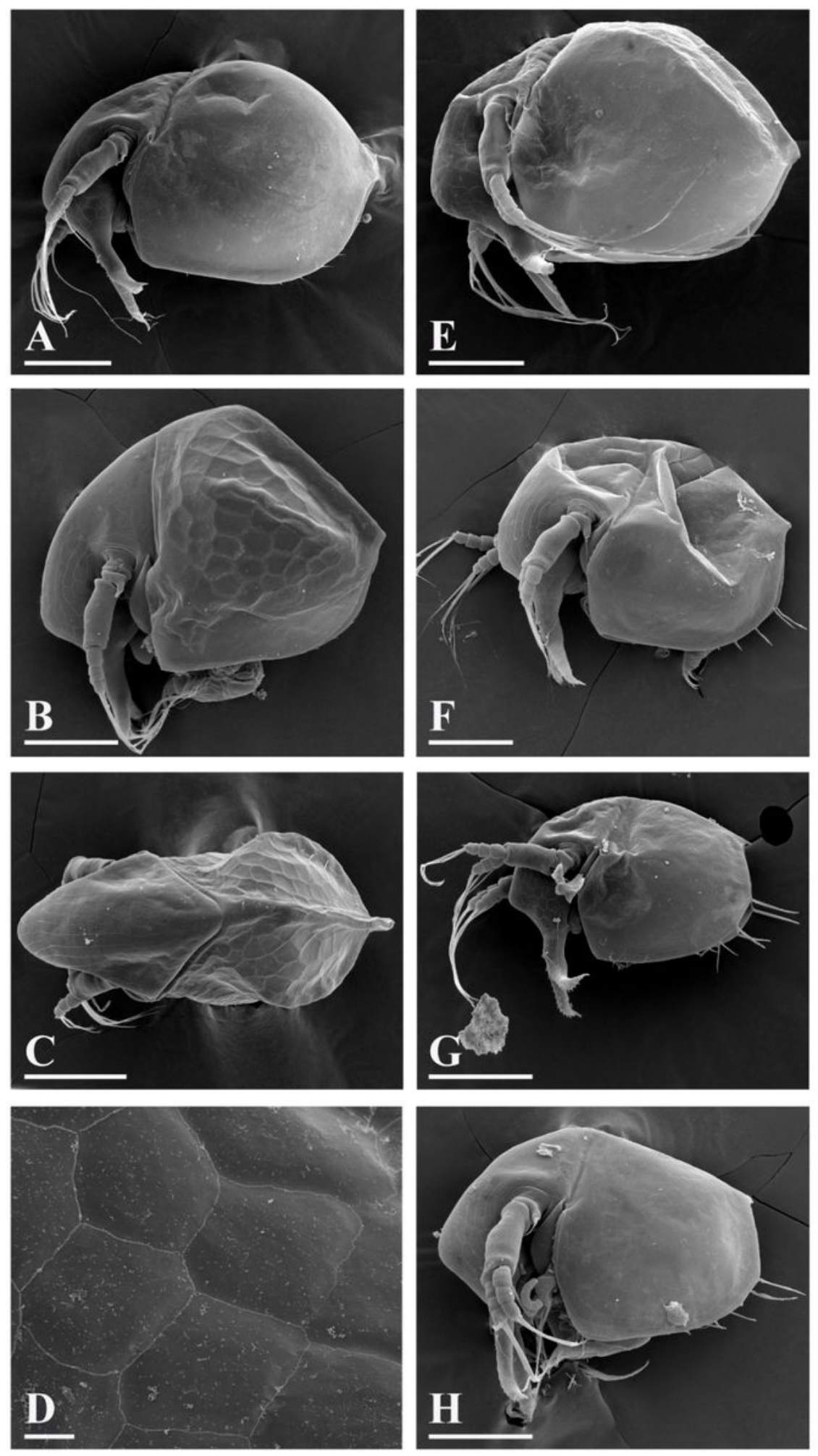

Figure 10

Bosminopsis zernowi Linko, 1900 from Sai-no-Kami Ike, Japan (A, C, G), Lake llinskoe, Primorsky Territory, Russia (B, D, F, H) and Lena River near Yakutsk, Yakutia Republic, Russia (E). A, Adult parthenogenetic female. B-D, Ephippial female in lateral and dorsal view and sculpture of ephippium. E, Pre-ephippial female. $F-G$, Juvenile female; $H$, Juvenile male II. Scale bars: $A-C, E-H=0.1 \mathrm{~mm}, D=0.01 \mathrm{~mm}$. 


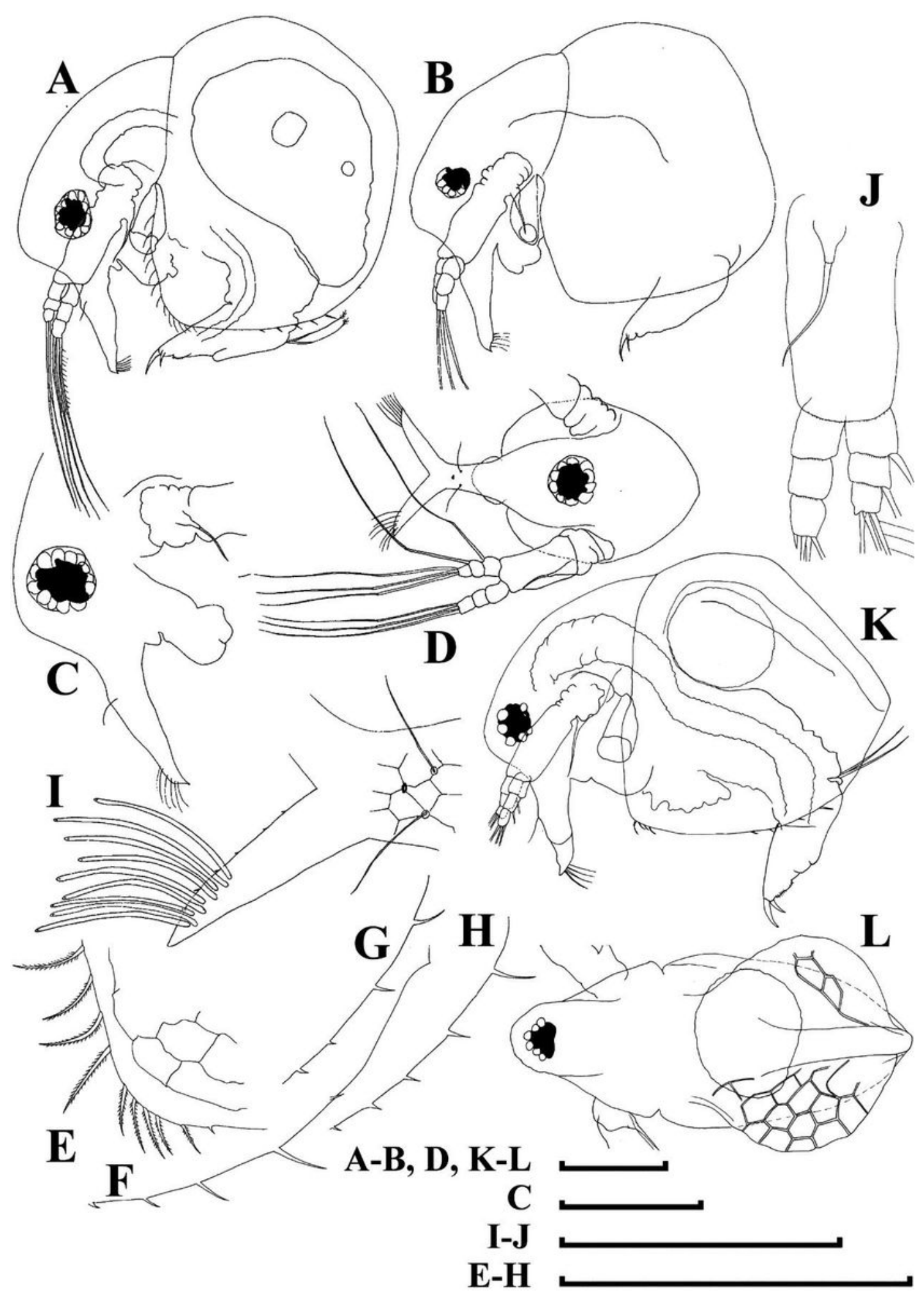

Figure 11

Bosminopsis zernowi Linko, 1901, large parthenogenetic females from Ivankovskoe Water Reservoir on Volga River, Tver' Area, European Russia (A-J) and mature ephippial female from a tributary of Dnepr River near Kremenchug, Poltava Area, Ukraine (K-L). A-B, Lateral view. C, Head, lateral view. D, Head, anterior view. E, Setae at antero-ventral valve portion. F-H, Spines at postero-ventral valve margin. I, Antenna I. J, Antenna II. K, Ephippial female, lateral view. L, Its dorsal view. Scale bars $=0.1 \mathrm{~mm}$. 


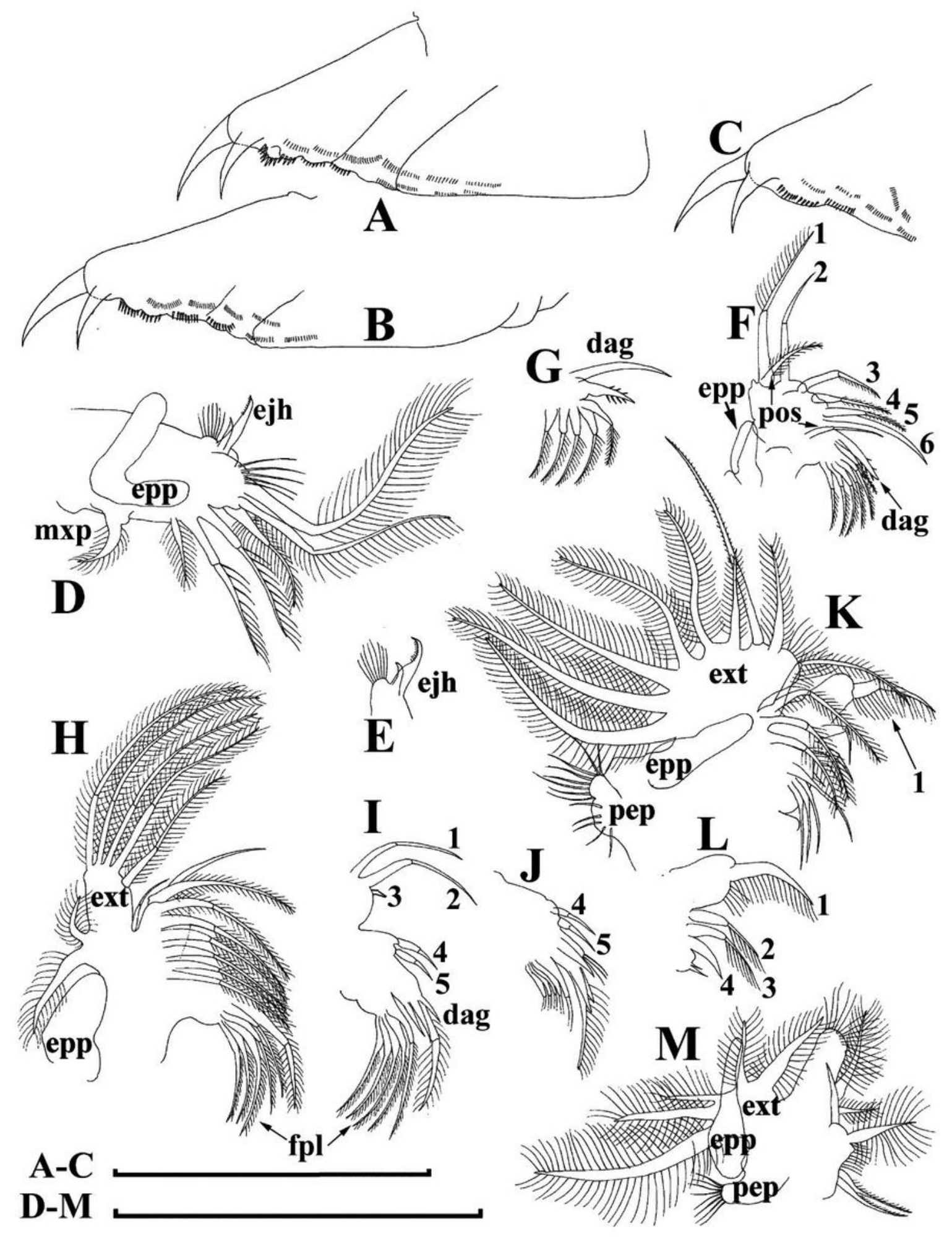

Figure 12

Bosminopsis zernowi Linko, 1901, parthenogenetic female Ivankovskoe Water Reservoir on Volga River, Tver' Area, European Russia. A-C, Postabdomen. D, Limb I. E, Ejector hooks I. F, Limb II. G, Distal armature of its gnathobase. H, Limb III. I, Its inner-distal portion. J, Granthobase III. K, Limb IV. L, Its inner-distal portion. M, Limb V. Scale bar $=0.1 \mathrm{~mm}$. 


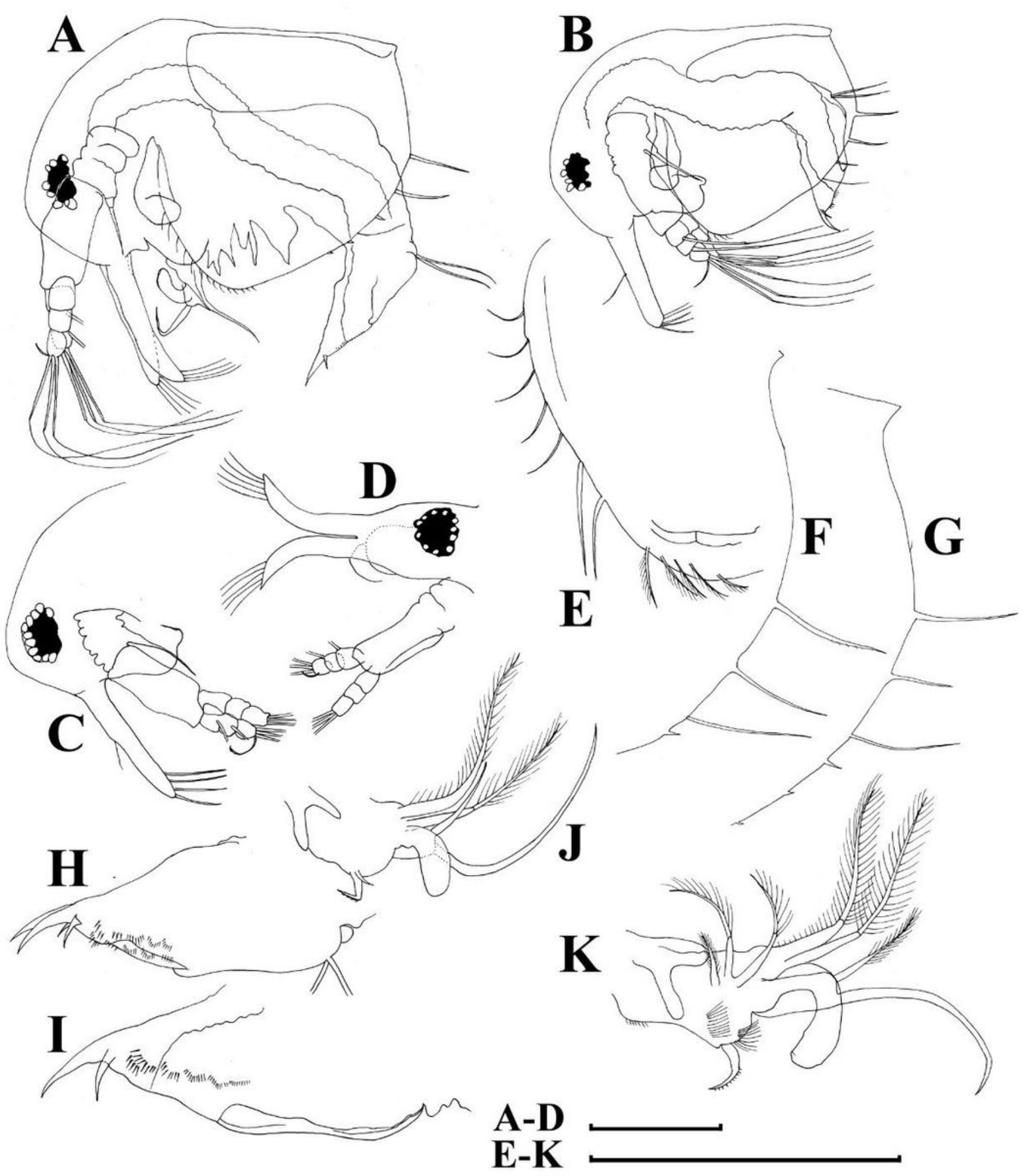

Figure 13

Bosminopsis zernowi Linko, 1901, juvenile male of instar II (A, C- G, I, K) and instar I (B, H, J) from Lake Livadijskoe, Primorski Territory, Far East of Russia. A-B, Lateral view. C, Head, lateral view. D, Its anterior view. E, Antero-ventral valve portion. F-G, Posterior portion of valve. $\mathrm{H}-\mathrm{I}$, Postabdomen. J-K, Limb I. Scale bars $=0.1 \mathrm{~mm}$. 


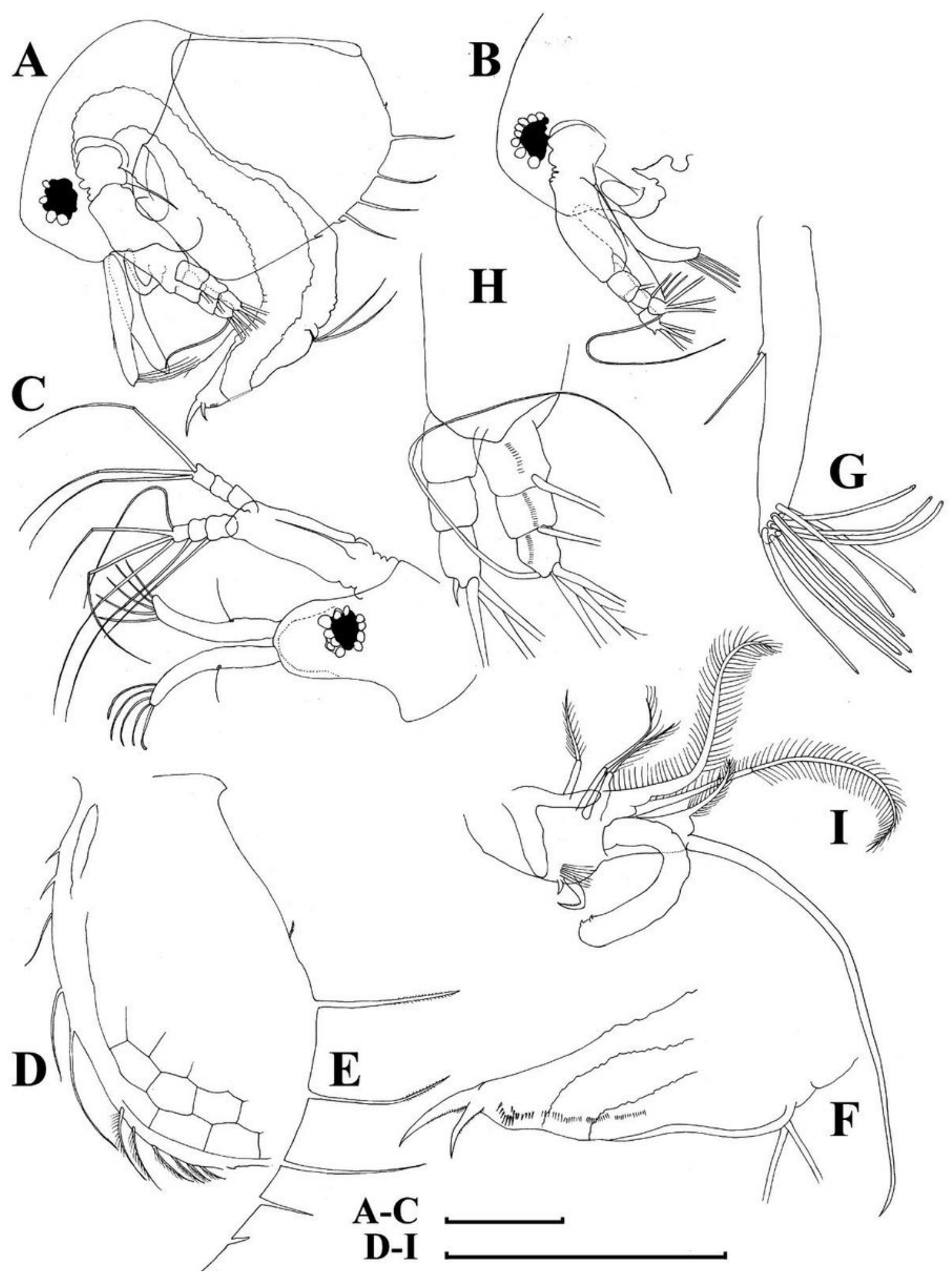

Figure 14

Bosminopsis zernowi Linko, 1901, adult male from Lake Livadijskoe, Primorski Territory, Far East of Russia. A, Lateral view. B, Head, lateral view. C, Its anterior view. D, Valve antero-ventral portion. E, Posterior portion of valve. F, Postabdomen. G, Antenna I. H. Antenna II. I, Limb I. Scale bars $=0.1 \mathrm{~mm}$. 


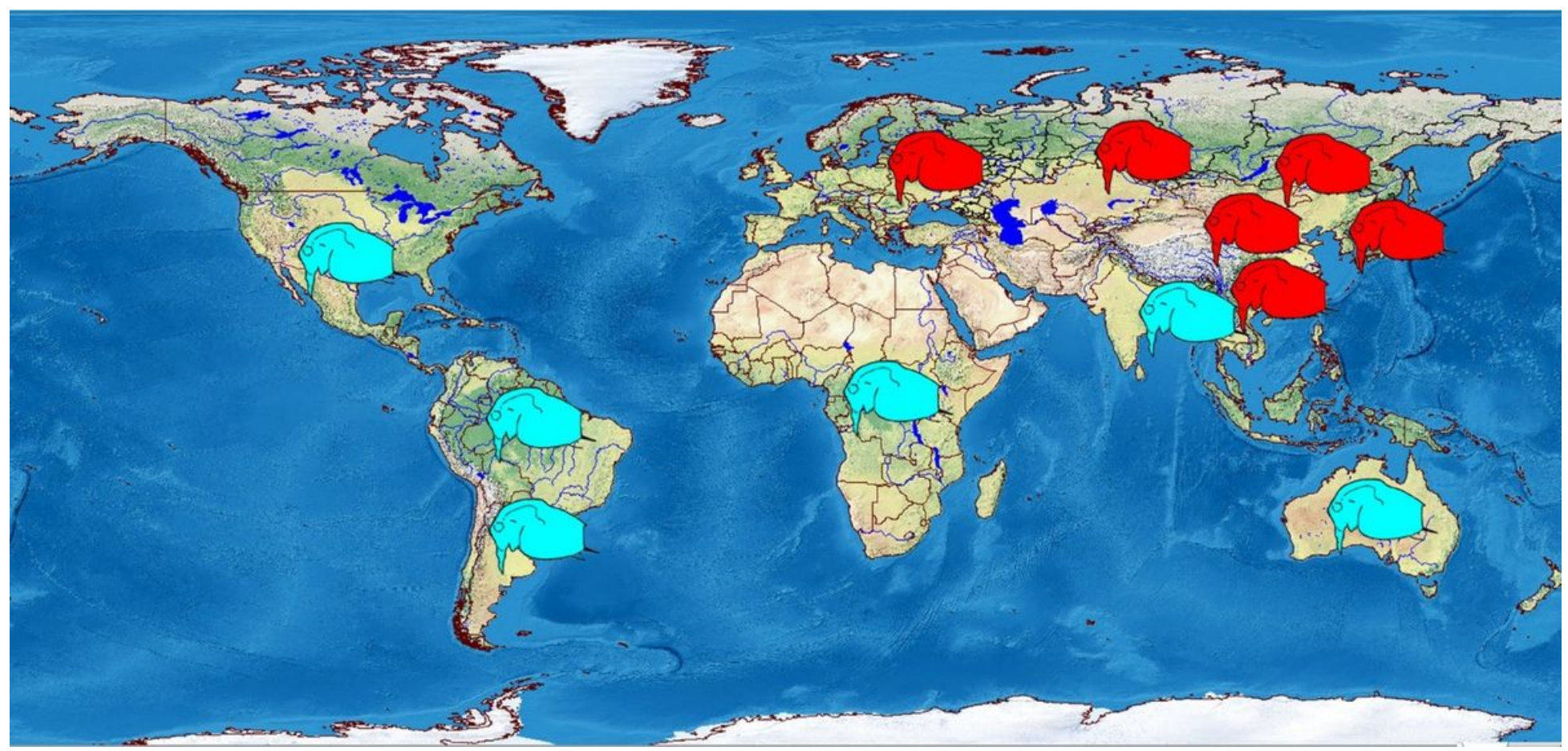

\section{Figure 15}

Schematic representation of distribution of two major morphotypes of the juvenile parthenogenetic female: with several mucro-like spines (red) and a single mucro (blue). Visualisation was made in free software DIVA-GIS7.5.0 (https://www.diva-gis.org) using free spatial GIS data from http://www.naturalearthdata.com as the layers. Symbols are inserted manually. Note: The designations employed and the presentation of the material on this map do not imply the expression of any opinion whatsoever on the part of Research Square concerning the legal status of any country, territory, city or area or of its authorities, or concerning the delimitation of its frontiers or boundaries. This map has been provided by the authors.

\section{Supplementary Files}

This is a list of supplementary files associated with this preprint. Click to download.

- Additional3SupplFigure1.tif

- Additional3SupplFigure1.tif

- Additional3SupplFigure1.tif

- Additional2SupplTable2.docx

- Additional2SupplTable2.docx

- Additional2SupplTable2.docx

- Additional1SupplTable1.xls

- Additional1SupplTable1.xls 
- Additional1SupplTable1.xls

Page 51/51 